\title{
Groundwater Surface (GWS) Mapping by Ground Penetrating Radar (GPR) For Use in Protecting Freshwater Habitats, Water Quality, and Active Dune Landscapes, In the Florence Coastal Dune Sheet, Oregon, USA
}

\author{
Curt D. Peterson ${ }^{1} \&$ Sarah R. Doliber ${ }^{2}$ \\ ${ }^{1}$ Geology Department, Portland State University, Portland, United States \\ ${ }^{2}$ Environmental Unit, Chenega Corporation, Charleston, United States \\ Correspondence: Curt Peterson, Geology Department, Portland State University, Portland, OR., 97207, United \\ States. Tel: 1-503-730-9266. E-mail: curt.d.peterson@gmail.com
}

Received: January 1, 2019

Accepted: January 16, 2019

Online Published: January 26, 2019

doi:10.5539/jgg.v11n1p13

URL: http://dx.doi.org/10.5539/jgg.v11n1p13

\begin{abstract}
Ground penetrating radar (GPR) profiling was performed in the Florence (FLOR) coastal dune sheet to test relations between remotely-sensed groundwater surface (GWS) trends, measured groundwater phreatic surfaces, and overlying freshwater features/habitats. Following preliminary GPR testing, the GWS trend mapping was employed in the north FLOR dune aquifer (17 km in length and $5 \mathrm{~km}$ in width), in anticipation of increasing development pressures on aquifer groundwater withdrawal by the City of Florence, Oregon. Several available technologies, including continuously-towed GPR profiling $(5-8 \mathrm{~km} / \mathrm{hr})$, real-time GPS positioning $( \pm 2 \mathrm{~m}$ horizontal), Lidar elevation control ( $\pm 0.5 \mathrm{~m}$ NAVD88), and GIS mapping/surface trend analyses permitted upscaling to the large management area $\left(40 \mathrm{~km}^{2}\right)$ in the north FlOR dune aquifer. Totals of $95 \mathrm{~km}$ of GPR trackline, including 943 averaged shot points at $100 \mathrm{~m}$ track-line intervals (total 100,000 shot points), were collected during a three-week field effort. The remotely sensed GWS, ranging from 1 to $14 \mathrm{~m}$ depth subsurface and 0 to 57 m elevation NAVD88, was ground-truthed in ponds, gaining-stream reaches, and monitored water wells. An area wide groundwater surface map confirmed a modeled dune-ramp aquifer, sloping (0.5-2.0\% gradients) to the Pacific Ocean shoreline and the dividing Siuslaw River valley. The continuous GPR profiles connected large dune barrage lakes, interdune valley window lakes, anadromous fish passage streams, and sensitive bog habitats to the locally-variable GWS $\left(0.98 \mathrm{R}^{2}\right.$ correlation coefficient). These elevated freshwater features were shown not to be developed on perched dune soil aquitards or lake bottom mud seals, but rather they are directly dependent on the mounded, variably sloping, and very-shallow GWS in the regional dune aquifer. Shallow GWS depths also promote colonization of active dune surfaces by non-native invasive dune grasses. The freshwater lakes and ponds were shown to be susceptible to contaminant transport by down-gradient GWS flows from surrounding residential and resort development.
\end{abstract}

Keywords: coastal dune, aquifer, groundwater surface, ground penetrating radar, lakes, ponds, wetlands

\section{Introduction}

The north Florence coastal dune sheet $\left(130 \mathrm{~km}^{2}\right.$ surface area) occurs within a larger complex of paleo-dune sheets (280 km in combined along-coast length and $500 \mathrm{~km}^{2}$ surface area) that exist between the Pacific Ocean and the temperate rainforest-covered foothills of the south-central Oregon coast (Figure 1) (Cooper, 1958; Reckendorf, 1975; Peterson et al., 2007a). Numerous lakes, ponds, and wetlands occur in the coastal dunes (Kavanagh, 1973; Daggett et al., 1996; Shultz, 1998; AOOL, 2018). Many of the lakes and ponds occur in upland coastal dune settings, 10-40 m above mean sea level (MSL), so they were assumed to represent 'perched' lakes, such as the world heritage McKenzie Lake, located at $75 \mathrm{~m}$ elevation in the large dune sand complex of Fraser Island, Queensland, Australia (Arthington and Hadwen, 2003). Such lakes and ponds were thought to be 'perched' on shallow bedrock surfaces, impermeable paleosols, lake bottom seals of mud and organic matter, and/or other isolated areas of elevated groundwater, within the permeable sand bodies. Following a federal agency request a small lake in the central FLOR dune sheet, Cleawox Lake, was investigated for sources of pollution (nitrogen and phosphorus) that could be related to increasing lake eutrophication. The elevation of Cleawox Lake (28 m MSL) 
suggested a 'perched' lake origin, thus apparently ruling out sources of pollution from surrounding campgrounds and residences, which would have drained vertically downward to an underlying water table. However, nearby water wells suggested otherwise- that Cleawox Lake was a window into an elevated regional groundwater surface (GWS), at about 25-30 m elevation. This controversial finding lead to ground penetrating radar (GPR) studies of GWS trends and dune surface water bodies in the FLOR dune sheet (Peterson et al., 2002a,b). Similar studies have been performed in beach plain dune aquifers in Oregon (Peterson et al., 2007b) and in other dune aquifers around the world (Harari, 1996; Doolittle et al., 2006; Rejiba et al., 2012; among others). The FLOR dune aquifer studies outlined in this article, conclude with a large scale GPR study of GWS trends in the north FLOR dune aquifer and their support of window lakes, ponds, and wetlands in the dune aquifer system (Doliber, 2012). The north FLOR dune aquifer is also the sole drinking water source for the City of Florence, Oregon, which expects to increase water withdrawal from the dune aquifer, pending anticipated future city growth (City of Florence, 2013). In this article, we present applications of available technologies, including continuous GPR profiling, GPS positioning, Lidar elevation control, and GIS surface trend analyses to map the regional GWS in coastal dune aquifers. The results of these studies have application to the regional mapping of GWS trends that influence coastal dune lakes, ponds, and wetlands, which could be susceptible to groundwater withdrawal, contaminant transport, and/or diminished dune aquifer recharge from future climate change.

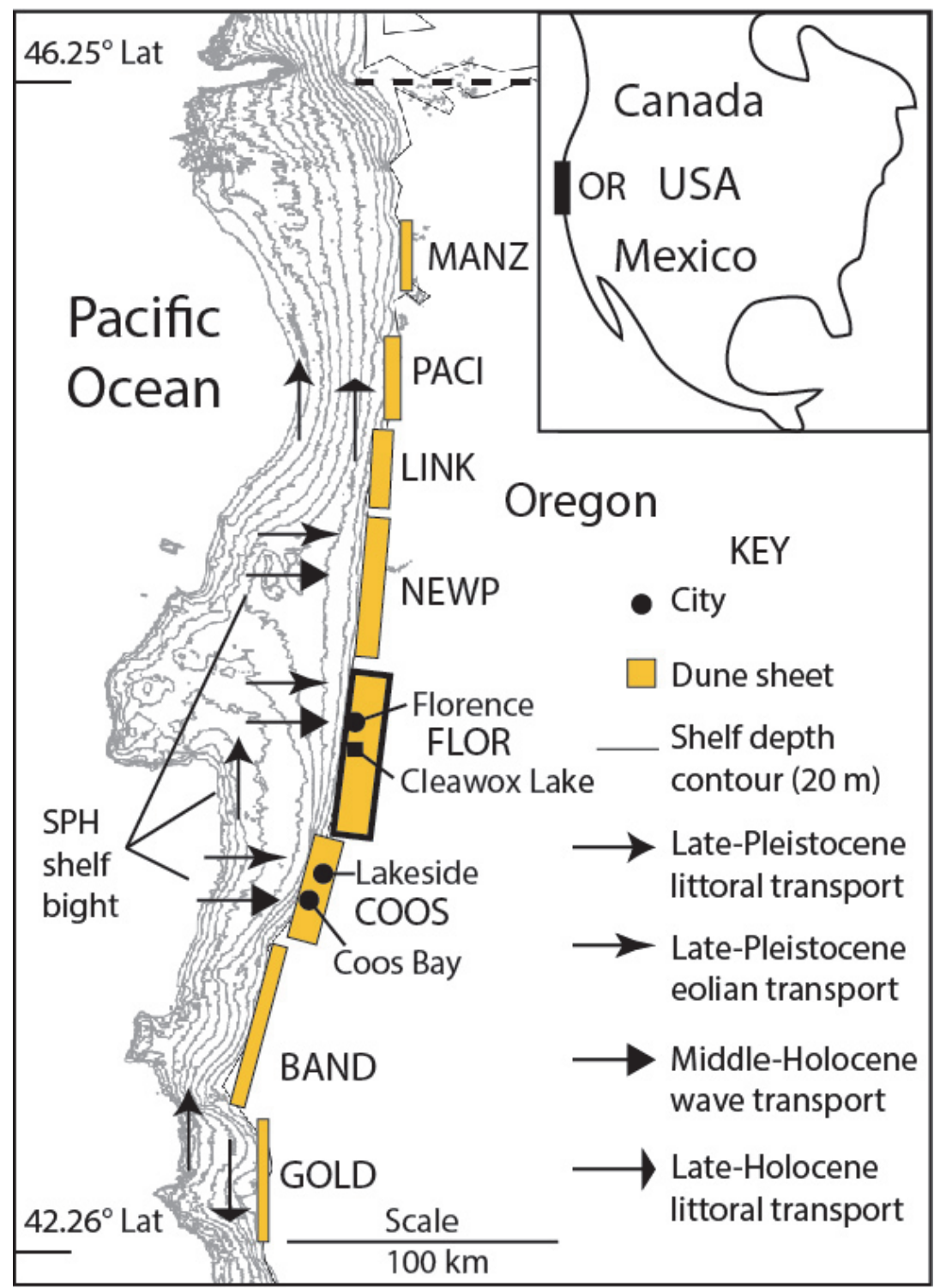

Figure 1. Location of study area Florence dune sheet (FLOR) in the central

Oregon coast. Littoral sand accumulated at the SPH shelf bight in late-Pleistocene time. It was then transported 
landward by wind and marine transgression to supply the Oregon upland dune sheets. Numerous lakes, ponds, and wetlands occur in the coastal dune sheets. One small lake in the central FLOR dune sheet, Cleawox Lake (solid square) served as a starting point to investigate the relations between lake levels and groundwater surface trends. A large dune aquifer in the north FLOR dune sheet supplies drinking water to the City of Florence, Oregon (solid circle). The groundwater surface (GWS) of the north FLOR dune aquifer was mapped by ground penetrating radar (GPR) in this study to aid the City of Florence in protecting the freshwater resources in the large dune aquifer.

\section{Background}

\subsection{Major Episodes of Oregon Dunes Development}

During late-Pleistocene marine low-stands (-50 to $-130 \mathrm{~m} \mathrm{MSL}$ ) the beach sand on the emerged Oregon continental shelf (Figure 1) was transported north by oblique ocean wave approach, to be trapped against a major continental shelf bight or projection, called the Stonewall-Perpetua-Heceta (SPH) banks (Peterson et al., 2007a). Paleo-beach sand was blown landward by eolian transport across the emerged middle- and inner-shelf to ramp-up against the foothills of the Coast Range, thus building the late-Pleistocene dune sheets ( $70-18 \mathrm{ka}$ in age). This semi-contiguous late-Pleistocene coastal dune complex thins to the north $(\sim 100 \mathrm{~km}$ distance $)$ and to the south $(\sim 100 \mathrm{~km}$ distance $)$ of the SPH low-stand depocenter, which was centered offshore of the FLOR dune sheet segment. The FLOR dune sheet ( $\sim 45 \mathrm{~km}$ along-coast distance) is arbitrarily bounded by modern littoral subcell boundaries of Heceta Head to the north and the Umpqua River Estuary to the south (Figure 2). The modern littoral subcell boundaries were not developed during the late-Pleistocene marine low-stand conditions, but they do separate Holocene dune accumulations (Peterson et al., 2007a; Peterson et al., 2009). The FLOR late-Pleistocene dune sheet (2-30 m in thickness) extends 2-6 km landward of the present shorelines and reaches up to $\sim 136 \mathrm{~m}$ in elevation MSL (Peterson et al., 2007a). Interstratified paleosol Fe/Al accumulation zones or B soil horizons (Birkeland, 1999) and coastal loess layers (Peterson et al., 2014) form localized hardpans in the late-Pleistocene dune deposits.
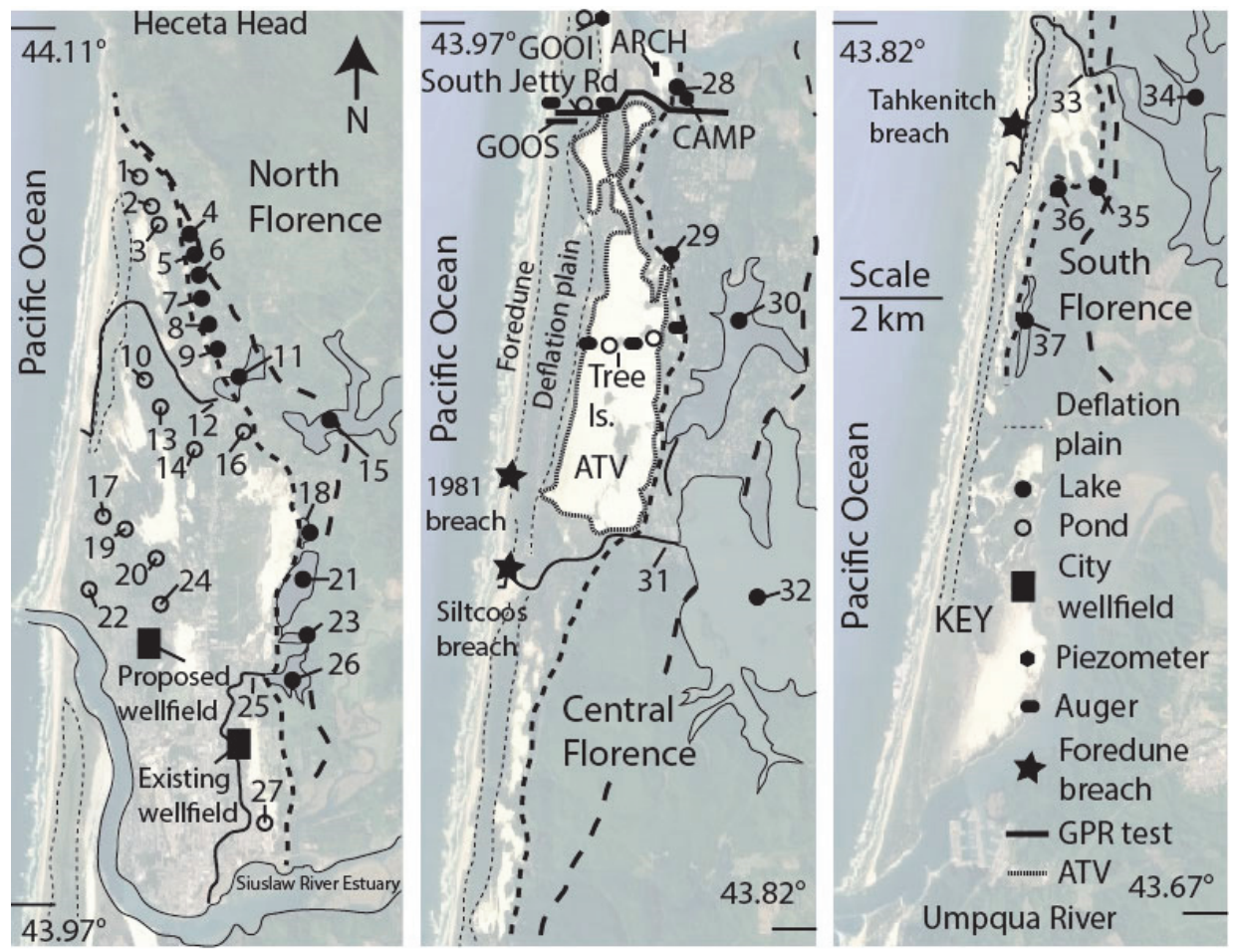

Figure 2. The FLOR dune sheet (north, central, and south) is shown from left to right

Numbered lakes and ponds are listed in Table 1. Existing and proposed wellfields (solid boxes) are shown in the north FLOR dune sheet/aquifer. Test GPR tracklines (bold line) are shown in the central FLOR dune sheet, as are piezometer wells (solid hexagon), artificial foredune breach sites (solid stars), and controlled ATV riding area (dotted line). Base map from Google Earth imaging (2016) (Google Earth, 2018).

The eolian landward transport of sand on the Oregon shelf was halted by the submergence of the middle- and inner-continental shelf during the Holocene marine transgression (16-0 ka). However, slowing of the marine 
transgression at about $9 \mathrm{ka}$, permitted onshore wave transport of remobilized shelf sand to reach the present coastline, with the earliest beach/dune deposits dated by radiocarbon to $8,365 \pm 47 \mathrm{cal}$ BP in the central FLOR dune sheet at the west end of the South Jetty Road (Figure 2B) (Peterson et al., 2006). The major landward advance of Holocene dune fields in the north FLOR dune sheet was underway by $7,745 \pm 77 \mathrm{cal}$ BP and $7.3 \pm 0.6$ ka by thermoluminescence (TL) dating (Peterson et al., 2007a). The Holocene dunes in the north FLOR dune sheet nearly reached their landward limit within $\sim 2,000$ years, barraging Munsel Lake (lake number 26 in Figure 2A) at $\sim 6.4$ $\mathrm{ka}$ (TL). Munsel Lake is located $\sim 3.1 \mathrm{~km}$ landward from the present ocean shoreline, with dunes on either side of the lake reaching 35-45 m elevation MSL. The middle-Holocene dune advance is responsible for the numerous dune barrage lakes and interdune ponds/wetlands (at least 20 in number) in the FLOR dune sheet (AOOL, 2018). The Holocene dune sheet thickness is measured to 5-30 m depth subsurface in the FLOR dune sheet (Couch et al., 1980). The Holocene dune sand is identified by a lack of cementation and no coastal loess interbeds, though weak paleosol Bw horizons (Peterson et al., 2006) are locally present where vegetative dune stabilization had occurred in prehistoric time.

\subsection{Dune Lakes, Ponds, Streams and Wetlands in the FLOR Dune Sheet}

The temperate rainforest that bounds the landward side of the FLOR dune sheet (Figure 2) receives 1.5-2.0 m yr${ }^{1}$ of precipitation as rain, primarily during winter-spring months (December to April) (AOOL, 2018). Freshwater lakes and ponds, at least 20 in number, abound on the eastern side of the FLOR Holocene dune sheet, where incised tributary valleys were flooded behind Holocene dune impoundments or dune barrages (Figure 5A) (Cooper, 1958). The elevations of the dune barrage lakes vary from 6 to $37 \mathrm{~m}$ MSL (Table 1). The landward tributaries of the largest barrage lakes are floored by Tertiary bedrock and/or late-Pleistocene dune deposits. However, the seaward ends of the barrage lakes are dammed by Holocene dune deposits. The smaller interdune ponds are all developed in Holocene dune deposits. Reported maximum depths in the dune barrage lakes range from 7 to $24 \mathrm{~m}$. The maximum depths of several lakes are close to $0 \mathrm{~m}$ MSL however, all the lakes are freshwater. The reported surface areas of the dune barrage lakes range from 1 to 1,280 hectares. The relatively-shallow dune barrage lakes generally range from mesotrophic to eutrophic, but the deepest lake, Clear Lake at $24 \mathrm{~m}$ maximum depth, is oligotrophic (Daggett, et al., 1996; AOOL, 2018). The largest dune barrage lakes have lake outlet streams or creeks that either connect to 1) adjacent barrage lakes or 2) cross the Holocene dune fields to reach the Pacific Ocean shoreline (Sutton, Siltcoos, and Tahkenitch Creeks) or to the Siuslaw River Estuary (Munsel Creek) (Figure 3B). The outlet streams that discharge into the ocean shoreline or the estuary during winter/spring months provide potential passage for endangered anadromous fish species, such as salmon and steelhead (ODFW, 2018). Those streams are identified in Table 1 as dune outlet streams. The discharges of the dune aquifer directly to ocean and estuarine shorelines, through shallow-subsurface interflows, are also important to dune-shoreline habitats. 

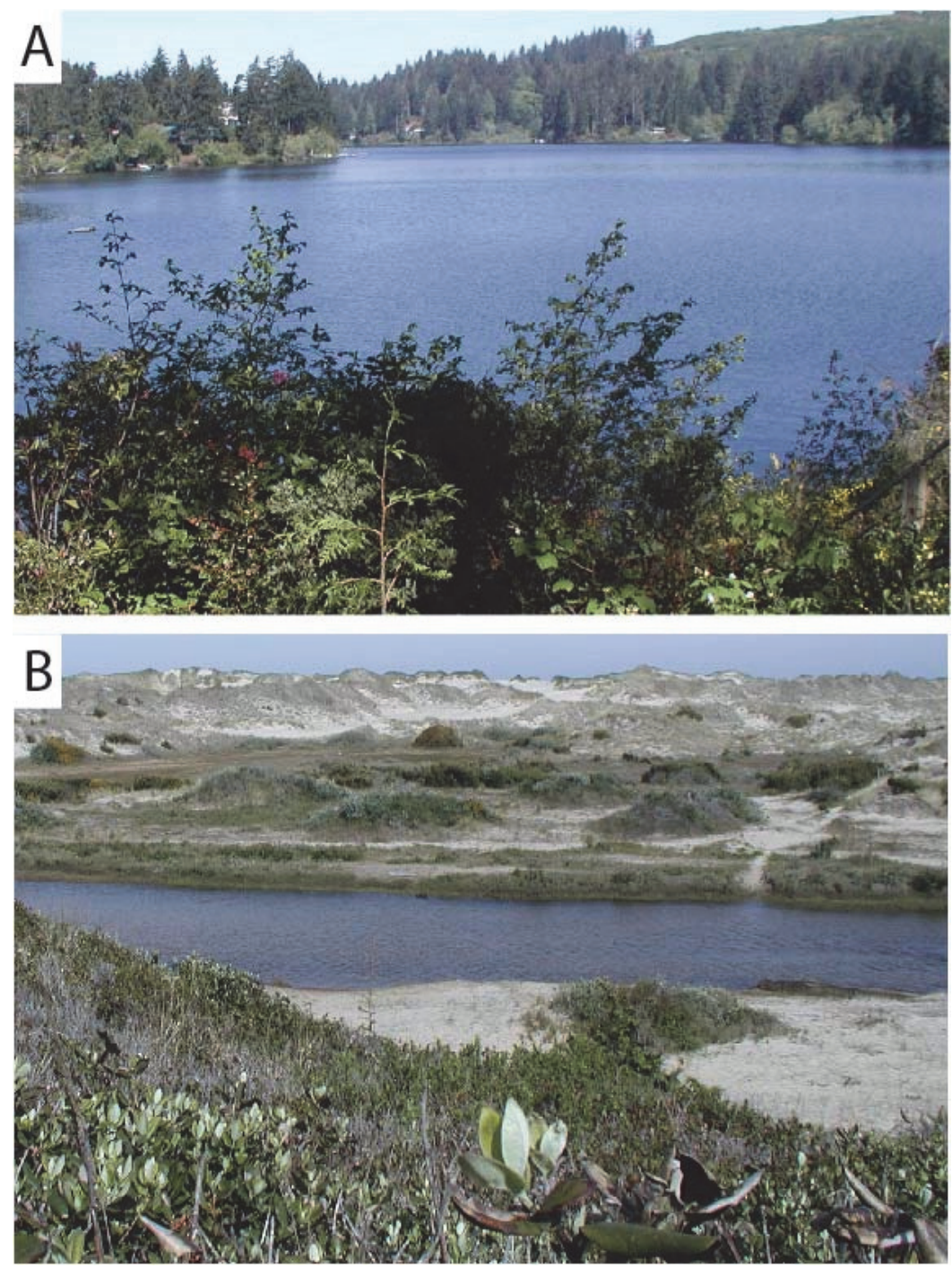

Figure 3. Part A. Photograph of a dune barrage lake, Mercer Lake, in the north

FLOR dune sheet (lake number 15 in Figure 2A, Table 1). Mercer Lake drains into the surrounding dune aquifer and into the dune-barraged Sutton Lake. Part B. Photograph of Sutton Creek, a dune outlet stream, which is connected to Sutton Lake and the surrounding dune aquifer (creek number 15 in Figure 2A, Table 1). Sutton Creek crosses a deflation plain (foreground) where it is diverted alongshore by large foredunes (background) before cutting out to the ocean shoreline. The deflation plain and foredunes are now stabilized by invasive dune grass. Rushes, sedges and willow have colonized the creek banks.

Table 1. Selected dune lakes, ponds, outlet streams, and wetlands in the FLOR dune sheet

\begin{tabular}{lllllll}
\hline Feature name & $\begin{array}{l}\text { Feature } \\
\text { type }\end{array}$ & Lat & Long & Surface area (hectares) & $\begin{array}{l}\text { Maximum } \\
\text { depth (m) }\end{array}$ & $\begin{array}{l}\text { Elevation } \\
\text { (m MSL) }\end{array}$ \\
\hline 1-Lilly Lk & IDP/IDW & 44.09253 & -124.11733 & 1 & 4 \\
2-Pond & IDP & 44.08560 & -124.11357 & $<1$ & 10 \\
3-Pond & IDP/IDW & 44.08176 & -124.11315 & $<1$ & 12 \\
4-Marr Lk & DBL & 44.08082 & -124.10720 & 1 & $17(19)$ \\
5-Nott Lk & DBL & 44.07530 & -124.10421 & $<1$ & $25(30)$ \\
6-Mussel Lk & DBL & 44.07291 & -124.10348 & 2 & $26(30)$ \\
7-Alder Lk & DBL & 44.07104 & -124.10378 & 1 & $27(37)$ \\
8-Dune Lk & DBL & 44.06704 & -124.10170 & 1 & 28 \\
9-Buck Lk & DBL & 44.06504 & -124.09981 & 1 & $28(37)$
\end{tabular}




\begin{tabular}{|c|c|c|c|c|c|c|}
\hline 10-Pond & IDW & 44.05501 & -124.11607 & 1 & & 17 \\
\hline 11-Sutton Lk & DBL & 44.05481 & -124.09324 & 43 & 11 & $13(10)$ \\
\hline 12-Sutton Ck & DOS & 44.05388 & -124.09684 & na & & 13 \\
\hline 13-Pond & IDP/IDW & 44.05278 & -124.10938 & $<1$ & & $17(36)$ \\
\hline 14-Pond & IDP/IDW & 44.05058 & -124.10749 & $<1$ & & 17 \\
\hline 15-Mercer Lk & DBL & 44.05038 & -124.07189 & 145 & 12 & $13(10)$ \\
\hline 16-Darl. Bog & IDW & 44.04645 & -124.09645 & $<1$ & & 20 \\
\hline 17-Pond & IDP & 44.03377 & -124.12531 & 1 & & 18 \\
\hline 18-Collard Lks & DBL & 44.03358 & -124.07846 & 17 & & $38(37)$ \\
\hline 19-Pond & IDP & 44.03200 & -124.11998 & 1 & & 22 \\
\hline 20-Pond & IDP & 44.02559 & -124.11007 & 4 & & 27 \\
\hline 21-Clear Lk & DBL & 44.02257 & -124.08042 & 62 & 24 & (30) \\
\hline 22-Pond & IDP & 44.02175 & -124.12757 & 3 & & 4 \\
\hline 23-Ackerley Lk & DBL & 44.01430 & -124.08190 & 5 & - & $29(30)$ \\
\hline 24-Pond & IDP & 44.01955 & -124.11024 & 7 & & 26 \\
\hline 25-Munsel Ck & DOS & 44.00853 & -124.08748 & & & 27 \\
\hline 26-Munsel Lk & DBL & 44.00722 & -124.08145 & 43 & 22 & (28) \\
\hline 27-Wetland & IDW & 43.98174 & -124.08894 & $<1$ & & 8 \\
\hline 28-Camp Lk & DBL & 43.95727 & -124.11521 & 1 & & 33 \\
\hline 29-Cleawox Lk & DBL & 43.93096 & -124.11453 & 35 & & 28 \\
\hline 30-Woahink Lk & DBL & 43.90929 & -124.10310 & 332 & 23 & 17 \\
\hline 31-Siltcoos Ck & DOS & 43.88182 & -124.11298 & na & & 6 \\
\hline 32-Siltcoos Lk & DBL & 43.87617 & -124.09011 & 1280 & 7 & 6 \\
\hline 33-Tahkenitch Ck & DOS & 43.80666 & -124.15134 & na & & 12 \\
\hline 34-Tahkenitch Lk & DBL & 43.79519 & -124.13104 & 677 & 7 & 12 \\
\hline 35-Elbow Lk & DBL & 43.78708 & -124.14930 & 7 & & 16 \\
\hline 36-Butterfly Lk & DBL & 43.78574 & -124.16238 & 2 & & 40 \\
\hline 37-Threemile Lk & DBL & 43.76006 & -124.17135 & 25 & & 16 \\
\hline
\end{tabular}

Feature numbers: 1-37. Feature types: dune barrage lake (DBL), dune outlet stream (DOS), interdune pond, (IDP), interdune wetland/bog (IDW). Deflation plain wetlands are not addressed in this table. Lakes are identified as such, when named (Google Earth, 2018). Lake surface areas (hectares), maximum depths (m), and surface area elevations (m MSL) are from the Atlas of Oregon Lakes (AOOL, 2018). Lidar lake elevations (m NAVD88) from this study are shown in parentheses (xx) (Doliber, 2012). Dune barrage streams or creeks are named from their dune barrage lake source. See Figure 2 for locations of mapped surface water features.

The interdune ponds and/or wetlands, generally 1-7 hectares in surface area, are widespread in the low- to midelevation ranges (4-27m MSL) in the FLOR dune sheet (Figure 2A, Table 1). Pond depths examined by these authors ranged from 1-3 m, though greater depths are reported for some interdune ponds. The interdune ponds that are listed for the north FLOR dune sheet in Table 1 formed in parabolic dune deflation troughs, so are elongate in shape. Some of the interdune ponds and wetlands, such as ponds numbered 10, 13, and 24 in Figure 2A and Table 1, showed seasonal shoreline changes of up to $1.0 \mathrm{~m}$ vertical fall from winter to late summer months (Figure 4A). A sensitive bog habitat, listed as number 16 in Figure 2A and Table 1, containing the carnivorous pitcher plant, Darlingtonia (Oregon State Parks, 2018), showed as much as $0.5 \mathrm{~m}$ of standing water level fall from winter to summer months during the year (2011) (Figure 4B). Wetland vegetation in the Florence dune sheet includes rushes, such as Juncus, and sedges, such as Carex, which survive seasonal standing water. Wetland forest plants that occur just above standing water include deciduous trees, such as willow (Salix hookeriana), and conifers such as Sitka spruce (Picea sitchensis). The colonizing plants such as the dune grasses, including the non-native species Ammophila arenaria, Ammophila breviligulata, and the native dune grass species Elymus mollis, and shore pine (Pinus contorta) are frequently present in recently-colonized dune wetland habitats (Christy et al., 1998). The most abundant wetlands in the FLOR dune sheet presently occur in the seasonally flooded deflation plains between vegetation-stabilized foredunes and the western slopes of the Holocene dune ramp (Figures 2 and 3B). The relations between the introduction of the non-native invasive dune grasses and the rampant colonization of remaining active dune surfaces are outlined below. 

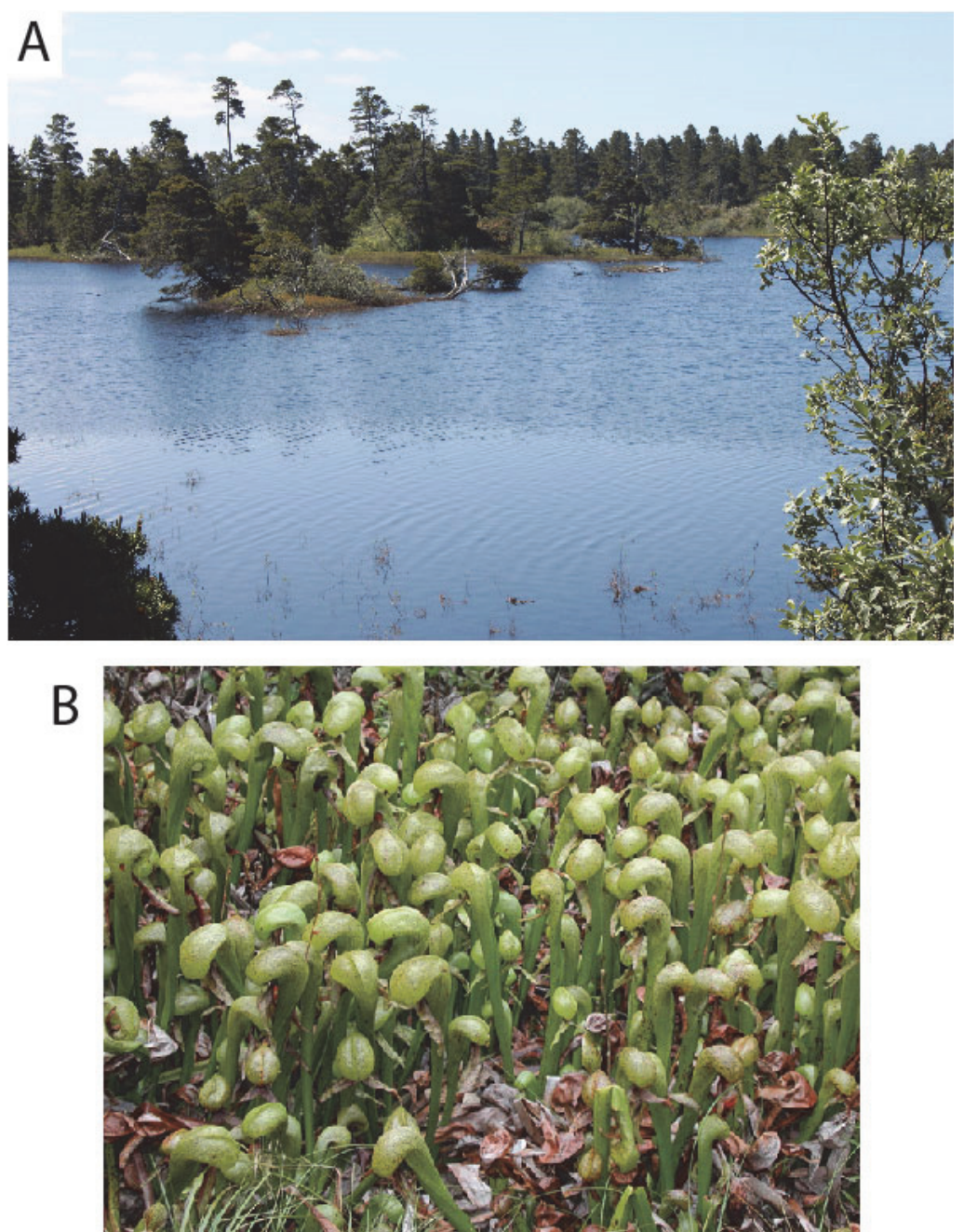

Figure 4. Part A. Photograph of Woods Lake, or pond number 24 in Figure 2A

and Table 1. The small interdune pond is located adjacent (north) to the proposed future City wellfield. The photograph of Woods Lake was taken at high water level (spring). View is to the south. Part B. Photograph of Darlingtonia or insect carnivorous pitcher plant, from the Darlingtonia bog in the north FLOR dune sheet, as numbered wetland 16 in Figure 2A and Table 1. The standing water level in the Darlingtonia bog dropped by as much as $0.5 \mathrm{~m}$ (vertical) during the dry summer months of 2011. The Darlingtonia bog is developed in a barraged paleo-dune hollow.

In the early 1900s plantings of two non-native dune grasses (European dune grass Ammophila arenaria and Eastern American beach grass Ammophila breviligulata) and shore pine (Picea sitchensis) were undertaken in the study area to stabilize the advancing dunes that were 'threatening' roadways and residences on the eastern side of the active dune fields (Hafenrichter, 1967; Carlson et al.,1991; USFS, 2018). The non-native dune grasses became invasive, spreading widely to stabilize the western slopes of the dune ramps and ridges (Heikkinen, 1994). Historic dune stabilization by invasive dune grass and other vegetation reduced the alongshore movements of dune sand and trapped sand on the upper windward slopes of the dune ramp ridges. Initial dune grass colonization occurs near ponds and seeps in deflation troughs of transverse and parabolic dunes, and at the toe or edge of retreating sand ramps (Figure 5). The invasive dune grasses also stabilized incipient foredunes, leading to foredune vertical accretion (Hacker et al., 2012). Continuing impacts from the dune grass stabilization of active dune fields in the FLOR dune sheet include 1) reduced snowy plover nesting habitat in narrowing beach backshores, 2) ongoing lowering of the deflation plains to the seasonal GWS, and 3) loss of active dune landscapes to succession by tall shrub and shore pine forests (Save Oregon's Dunes, 2016). The only management practice that has successfully forestalled the loss of active dune surfaces by the invasive dune grass colonization has been from controlled recreational All-Terrain-Vehicle (ATV) riding. 

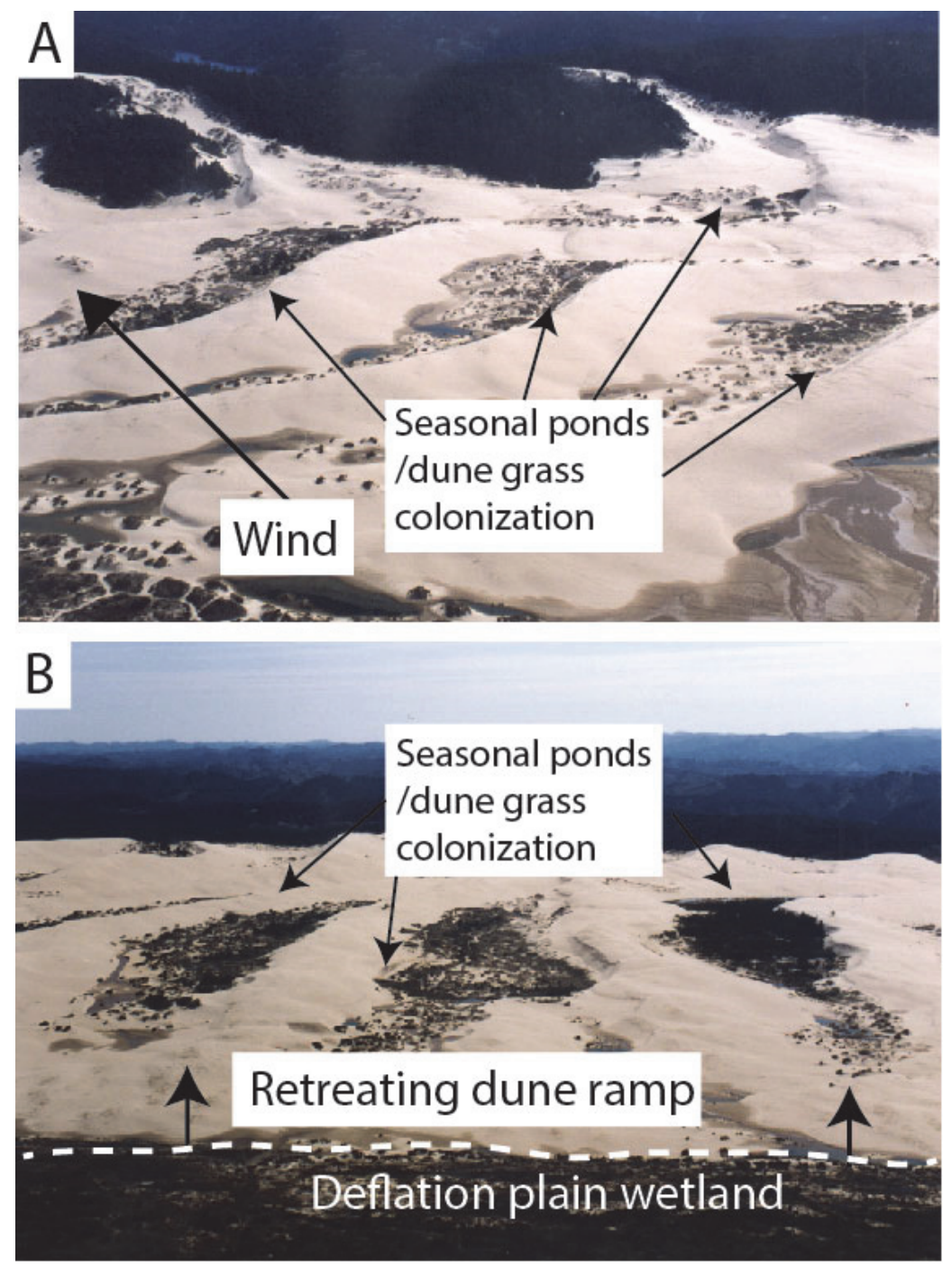

Figure 5. Part A. Vegetative colonization (dark shades) of dune ramps in the

FLOR and COOS dune sheets by the invasive dune grasses (European and Eastern American) is initiated near seasonal ponds and seeps in dune deflation troughs. Transverse dunes (straight crested) transition up-slope to parabolic dunes (elongate) in the large dune ramp/ridge western slopes (Cooper, 1958). The transverse dunes are oriented northeast (migration direction) due to strong winter storm winds from the southwest (Hunter et al., 1983), though summer northwest winds also influence smaller dune migrations. Part B. A net landward retreat of the dune ramp (large arrows) results in widening of the deflation plain, lowering of the dune surface to seasonal flooding elevations, and eventual stabilization by wetland vegetation. Oblique air photos (2003) are from an area northeast of Lakeside in the COOS dune sheet (Figure 1), with views to the east (Part A) and southeast (Part B).

\subsection{North FLOR Dune Aquifer}

The City of Florence, with a population $\sim 8,600$, is currently served by 13 water wells in one wellfield located in the north FLOR dune aquifer (Figure 2A) (City of Florence, 2013). A smaller wellfield (Heceta Beach) is developed north of the City of Florence. A wastewater treatment plant discharges the City's treated water into the Siuslaw River Estuary. Both private water wells and septic systems are distributed in outlying areas in the north FLOR dune aquifer. The City's current wellfield capacity is 10.2 million liters per day (mld), but the City's existing groundwater rights total 14.4 mld (GSI Water Solutions, 2012). Expansion of the City's drinking water treatment plant to $15 \mathrm{mld}$ is considered feasible, but future City growth could require additional water wells in a new wellfield within the dune aquifer system (Figure 2A). A groundwater flow model was developed to help the City protect this potential future source of drinking water in the dune aquifer (GSI Water Solutions, 2012). The flow model was calibrated/verified by monitoring wells and a GWS map produced from GPR profiling in the north FLOR dune 
sheet (Doliber, 2012), as summarized in this article. In addition to model calibration and verification, the regional GWS map was used to identify environmentally sensitive freshwater habitats that could be impacted by contaminant transport and/or aquifer GWS drawdowns, as addressed in the Discussion section of this article.

The north FLOR dune aquifer extends under the north FLOR dune sheet from Hectea Head to the Siuslaw River (15 km length) and from the Pacific Ocean shoreline to the landward extent of the dune deposits (4 km length), which ramped up against the foothills of the Coast Range (Figure 2A) (Hampton, 1963). A study of the dune aquifer thickness was undertaken by seismic refraction profiling (Couch et al., 1980). The dune aquifer contains 1) deep troughs $(\sim 30-60 \mathrm{~m}$ depth subsurface) of weakly cemented late-Pleistocene estuarine-sands, trending north-south on the west and east sides of the aquifer basin and 2) overlying weakly-cemented late-Pleistocene dune sand and uncemented Holocene dune sand (0-30 m depth subsurface). For the purposes of this article the GWS in the north FLOR dune aquifer is entirely hosted in well-sorted paleo-dune sand deposits. Aquifer recharge is from direct infiltration of precipitation in the dune sheet (average annual rainfall $\sim 1.75 \mathrm{~m} \mathrm{yr}^{-1}$ ). Reported hydraulic conductivity values $(\mathrm{K})$ of $1.7 \times 10^{-3} \mathrm{~cm} \mathrm{~s}^{-1}$ to $1.8 \times 10^{-2} \mathrm{~cm} \mathrm{~s}^{-1}$, are relatively high in both the Holocene and Pleistocene dune deposits (GSI Water Solutions, 2012). Due to high meteoric water recharge, the model projected wellfield drawdowns and deep aquifer contaminant transport, under current withdrawal rates, that are localized to within a few kilometers radius of the wellfield(s). However, potential non-point source contaminations of surface water bodies are of concern within the broader extents of the sole source dune aquifer system (City of Florence, 2013).

\section{Methods}

\subsection{GPR Testing in the FLOR Dune Sheet}

The use of GPR to remotely and continuously measure the subsurface depth to the GWS was tested in two short transects (100-300 m distance) in a dune ramp slope (ARCH) and a deflation plain wetland (GOOS), as accessed from the South Jetty Road in the central FLOR dune sheet (Figure 2B) (Harry Jol, unpublished data, 1994; 2001; Peterson et al., 2002a,b). A Sensors and Software PulseEkko100 (1000 v) GPR system was used with $100 \mathrm{MHz}$ unshielded antennae that were hand carried to record digitally stacked signal returns (16 stacks per step) at 0.5 or $1.0 \mathrm{~m}$ step spacing (Figures 6 and 7). Track line topographic data were collected with a laser level. The GPR profile records were output in wiggle-trace format, that showed the polarized ground water surface reflection (Daniels, 1996) cutting through dune cross-bedding reflections (Figure 6B) and lying between sub-horizontal accretion reflections (Figure 7B). Hand auger and mud rotary drilling were used to ground-truth depths to the phreatic GWS and to calibrate GPR signal velocity in fully water-saturated sand $\left(0.07-0.08 \mathrm{~m} \mathrm{~ns}^{-1}\right)$, dry loose sand $(0.11-0.12 \mathrm{~m}$ $\left.\mathrm{ns}^{-1}\right)$, and moist compacted sand $\left(0.09-0.11 \mathrm{~m} \mathrm{~ns}^{-1}\right)$. The theoretical depth resolution of GPR reflections is $1 / 4$ to $1 / 2$ of the wave length, where wave length=velocity/frequency (Jol and Bristow, 2003). Assuming a $0.1 \mathrm{~m} \mathrm{~ns}^{-1}$ signal velocity, the $100 \mathrm{MHz}$ antennae should yield $\sim 0.5 \mathrm{~m}$ depth resolution to target reflectors. 


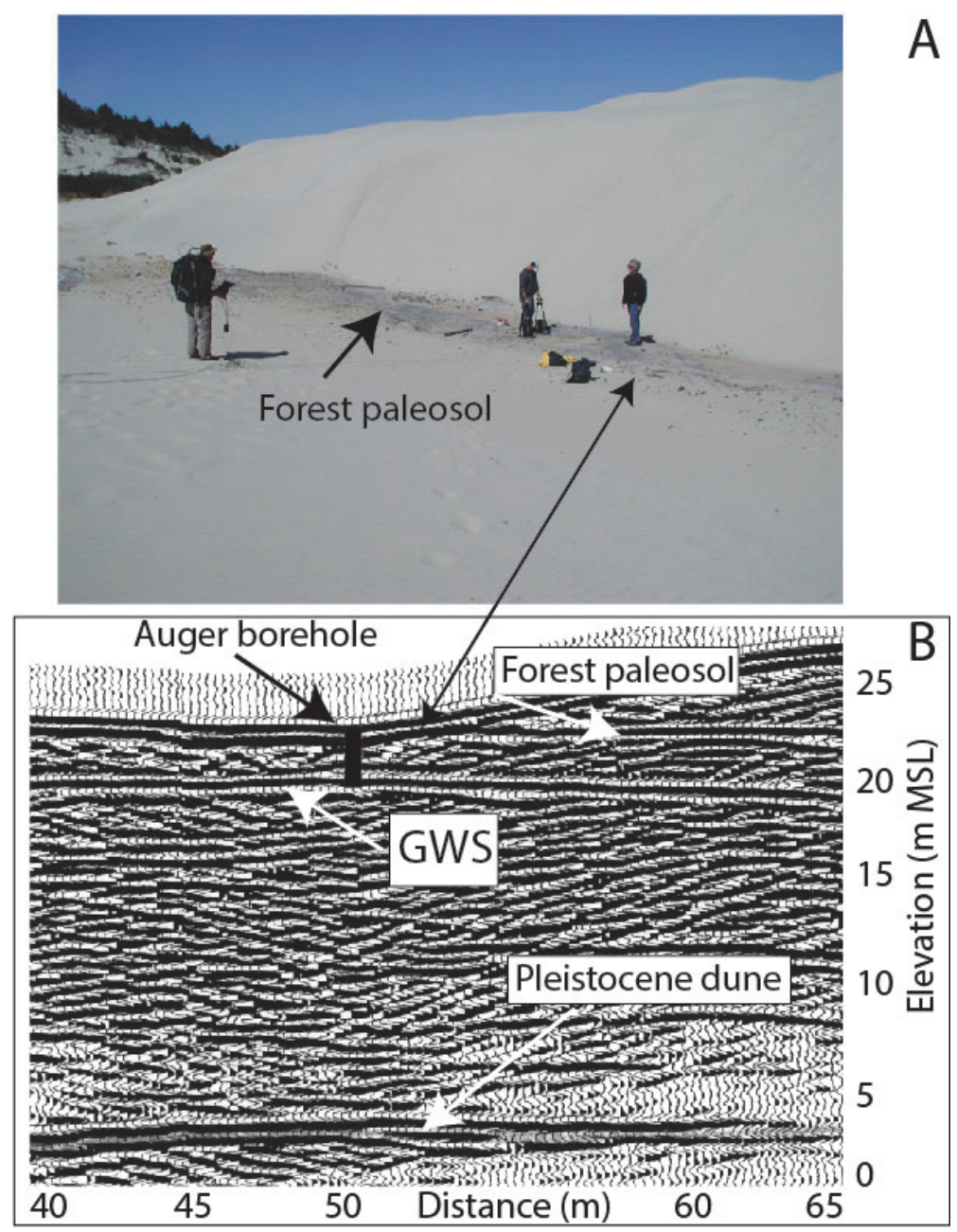

Figure 6. Part A. Photograph of ground penetrating radar (GPR) profiling to

establish relations between an archeological site (Forest paleosol), episodically occupied $\sim 2.3$ to 0.5 ka (Minor et al., 1999), and a suspected underlying GWS in the ARCH transect (see location in Figure 2B). Part B. GPR profile showing the GWS reflection at $2.5 \mathrm{~m}$ depth below the Forest paleosol. The phreatic GWS (standing water) in the auger borehole coincided with the GWS reflection at $2.5 \mathrm{~m}$ depth subsurface, or $20 \mathrm{~m}$ elevation MSL on the northwestern slope of Holocene dune ramp. The underlying Pleistocene dune surface (20-25 m depth subsurface) is dated to $24.6 \pm 3.1 \mathrm{ka}$ (TL) in the adjacent Siuslaw River bank (Peterson et al., 2007a). 


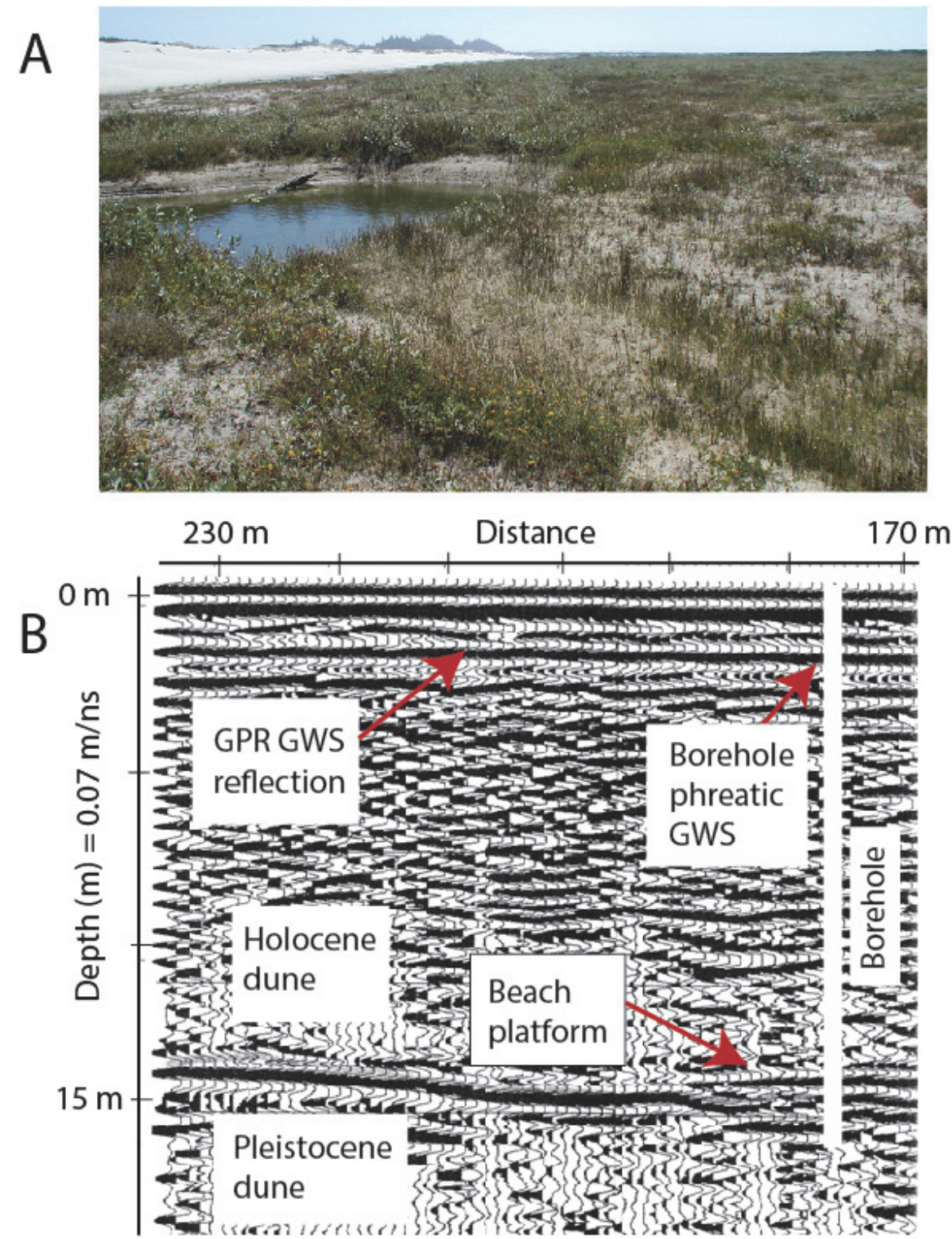

Figure 7. Part A. Borrow pit pond filled with water (summer) in Goose Pasture

deflation plain, located $\sim 100 \mathrm{~m}$ landward of the foredune in the central FLOR dune sheet (photograph view is to the south) (see location in Figure 2B). The ground water surface (GWS) is locally $\sim 1.0 \mathrm{~m}$ below the averaged hummocky dune surface. A nearby piezometer monitoring well (GOOI) showed $\sim 0.5 \mathrm{~m}$ vertical change of the phreatic GWS surface in the deflation plain over the course of one year (John Baham and George Grathoff, unpublished data, 2002). Colonizing dune grass roots (live) reached 2-5 $\mathrm{m}$ depths subsurface, as logged in borehole sites in the deflation plain dune deposits in the South Jetty Road (Figure 2B). Part B. GPR profile across the deflation plain (GOOS transect) along the west end of South Jetty Road (Figure 2B). A rotary mud borehole confirmed 1) saturated water conditions, or phreatic GWS surface, at the corresponding GWS reflection (1.0-2.0 $\mathrm{m}$ depth) and 2) the Holocene dune/beach contact ( $~ 8 \mathrm{ka})$ with the underlying late-Pleistocene dune deposits at 14 $m$ depth surface (Peterson et al., 2006).

In 2011, preliminary tests of upscaling the GPR profiling to regional GWS trend mapping were conducted over several multi-kilometer distances in the central FLOR dune sheet with a Pulse EkkoPro 1000 v GPR system, and either $100 \mathrm{MHz}$ or $50 \mathrm{MHz}$ unshielded antennae, that were towed behind a continuously moving vehicle (Figure 8). One long traverse (3.4 km in track line distance) was profiled for continuous depth to GWS across the large Holocene dune ramp/ridge ( $\sim 50 \mathrm{~m}$ elevation) via the South Jetty Road in the central FLOR dune sheet (Figure 2B). Track line distances were recorded by GPR odometer trigger/wheel, between GPS georeferenced control points. The vehicle towed GPR was operated at speeds of $5-8 \mathrm{~km} \mathrm{hr}^{-1}$, thereby increasing the track line distance 
coverage rate by up to $10 \mathrm{x}$, relative to the hand carried GPR profiling method (Figure 6A). Though the low gradient GWS reflection was well recorded by the continuously towed antennae, the dune internal cross-bedding reflections were attenuated. The deeper GWS reflections ( $>5 \mathrm{~m}$ depth subsurface) in the north FLOR dune aquifer survey, as outlined below, were enhanced in grayscale output format by applying an algorithm, termed spreading and exponential compensation (SEC), during GPR record post-processing, using ProEkkoViewDeluxe software (Doliber, 2012).
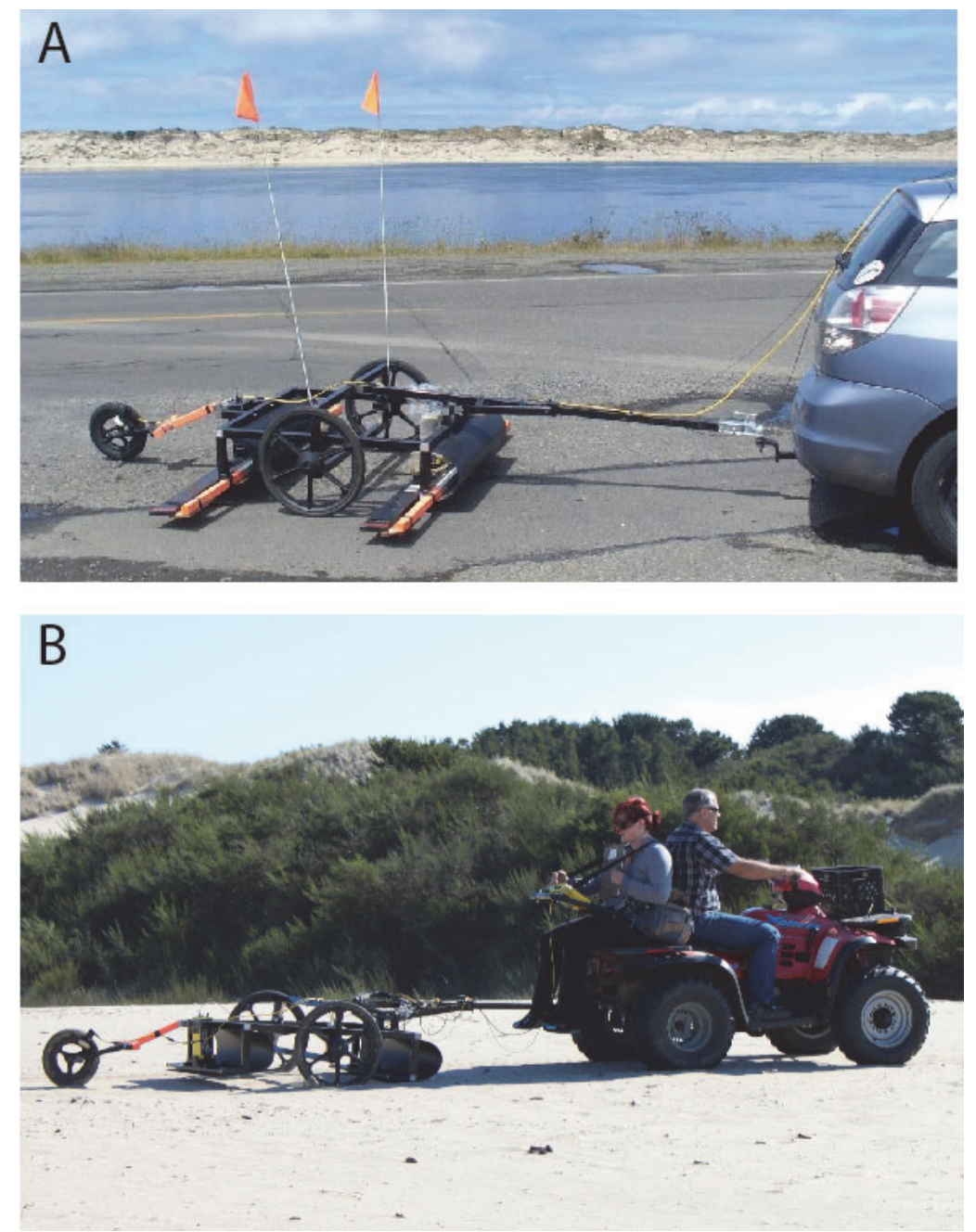

Figure 8. Part A. Pulse EkkoPro 1000 v GPR with $50 \mathrm{MHz}$ antennae towed

behind a vehicle for surveying regional GWS trends on city streets. The $50 \mathrm{MHz}$ antennae are $2.0 \mathrm{~m}$ in length. In broadside orientation, the trailer width took one full lane of roadway. Vehicle speed was $5-8 \mathrm{~km} / \mathrm{hr}$. Siuslaw River estuary is in background. Part B. Pulse EkkoPro 1000v GPR with $100 \mathrm{MHz}$ antennae (1.0 m length) towed behind an ATV for open dune sand surveying. Digital video logger (DVL) for recording GPR data and GPS receiver, for recording track line position data were carried by the GPR operator (facing the towed GPR antennae).

To efficiently cover the broad extent of the north FLOR dune sheet ( $40 \mathrm{~km}^{2}$ surface area) by vehicle-towed GPR surveying, the study area was divided into south and north halves (Figure 9), as surveyed during a three-week interval (summer 2011). The south half, including the City of Florence and the City water wellfield(s), was densely covered by orthogonal-crossing GPR track lines in City streets and access roads. Selected GPR track lines intersected two large barrage lakes, several large interdune ponds, and Munsel Creek (creek number 26 in Figure 2A and Table 1), an endangered anadromous fish passage stream (City of Florence, 2013). In the less densely populated northern half, the GPR track lines were limited to several major north-south and east-west roadways that intersected two large barrage lakes, several interdune ponds and associated wetlands, and the sensitive pitcher plant (Darlingtonia) bog (pond/wetland number 16 in Figure 2A and Table 1). 
A total of 73 ground-truthing locations included measured height differences between GWS reflections, as recorded below road grade in GPR profiles, and adjacent subaerial water surfaces in adjacent lakes, ponds, wetlands, and shallow creeks (Doliber, 2012). The interpreted depths to GWS were also validated at the City's production wells and test monitoring wells (GSI Water Solutions, 2012). A best-fit signal velocity of $0.10 \mathrm{~m} \mathrm{~ns}^{-1}$ was established for dry/moist dune deposits above the GWS reflections in the study area. The post-processed GPR lines were evaluated for GWS subsurface depths, at $10 \mathrm{~m}$ intervals along the GPR track lines, as recorded by odometer wheel, GPS controlled endpoints, and GIS satellite image cross-referencing. Position accuracy is estimated to have been $\pm 2 \mathrm{~m}$ NAD83. Road surface elevations at GWS depth intervals were extracted from a Lidar digital elevation model (USGS, 2011) using geographic information system (GIS) ArcMap Software (Doliber, 2012). The GWS depths and corresponding elevations, normalized to the NAVD88 datum (0 m NAVD88 is about $-1 \mathrm{~m}$ MSL in the study region), were then averaged over $100 \mathrm{~m}$ track line distance intervals. Interpreted GWS depths are estimated to have $\pm 1 \mathrm{~m}$ vertical resolution. Averaging the GWS over $100 \mathrm{~m}$ track line intervals also helped to reduce interpretation uncertainties from locally bifurcated, attenuated, or offset GWS reflections, (Doliber, 2012).

A total of 43 GPR survey lines (Figure 9), covered 95 kilometers of GPR track-line distance and included 943 GWS depth/elevation data points $(100 \mathrm{~m}$ intervals $)$, as averaged from $\sim 10,000$ measured shot points $(10 \mathrm{~m}$ intervals), as subsampled from $\sim 100,000$ collected shot points ( $1 \mathrm{~m}$ step spacing). Several GPR track lines were repeated in reversed directions or with different vehicle speeds to verify GWS reflection interpretations. Details on spatial kriging of GWS point data for constructing contoured maps of GWS depths and GWS elevations are provided in Doliber (2012). All north FLOR dune aquifer GPR profiles, as outputted in unmarked topographicallycorrected high-resolution grayscale format, are provided in Doliber (2012).

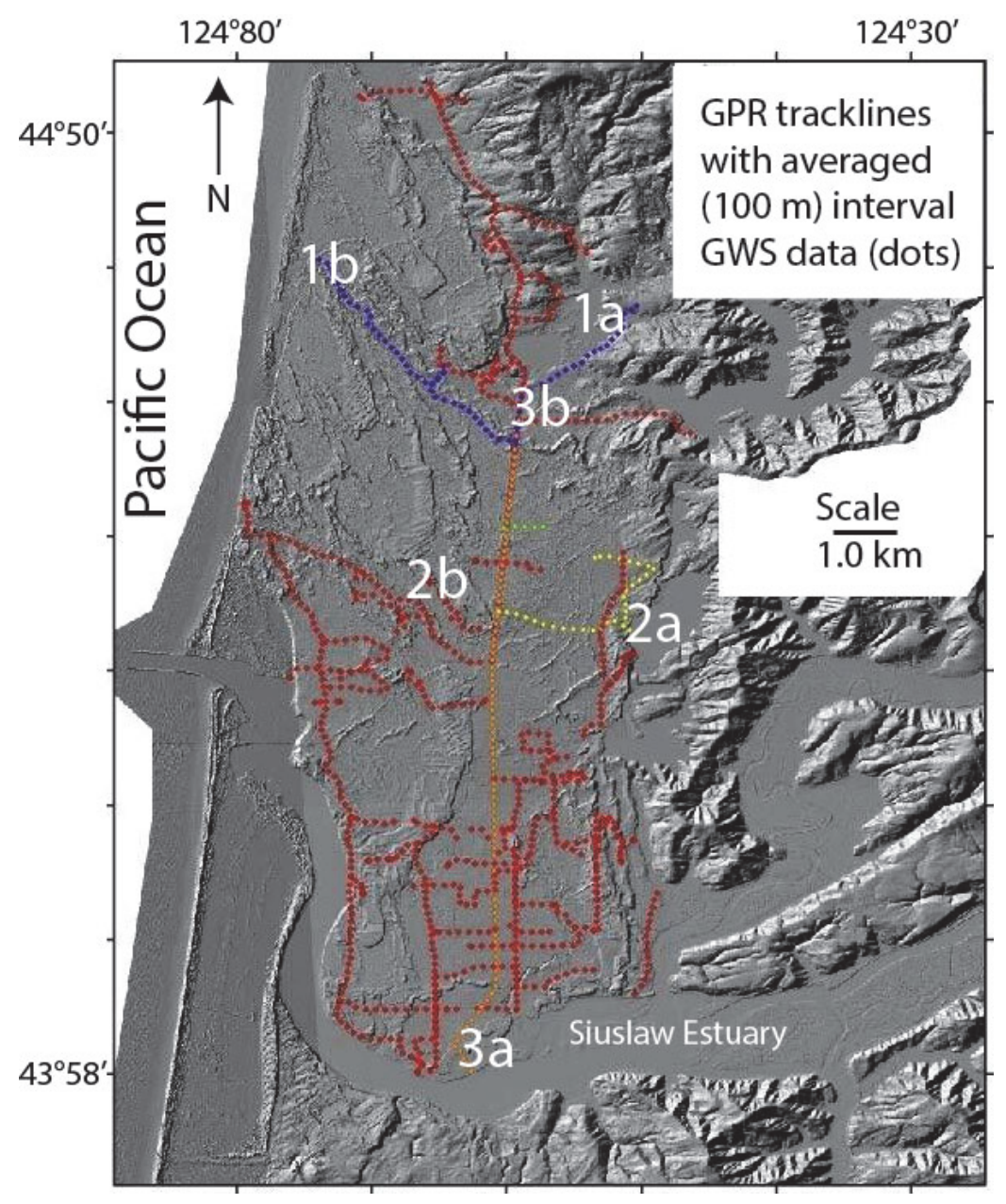

Figure 9. GPR track lines are shown for the GWS survey in the north FLOR dune

sheet, as plotted on a Lidar hill-shaded topographic relief map. Key track lines include a north-south survey (orange) from position 3a (Siuslaw Estuary shoreline) to $3 \mathrm{~b}$, an east-west survey (purple) from position 1a (Sutton Lake) to 
position $1 \mathrm{~b}$ (Sutton Creek deflation plain), and a shorter east-west survey (yellow) from position 2a (Clear Lake) to position $2 \mathrm{~b}$ (central high dune), in the north FLOR dune sheet (see Figure 2A and Table 1 for numbered/named lake and creek locations).

\section{Results}

\subsection{Dune Lakes, Ponds, and Wetlands Supported by Groundwater Surface (Window Lakes)}

Color near-infrared photography was used to remotely sense the presence of seasonal (spring) surface water features in the Tree Island traverse test area in the central FLOR dune sheet (Figure 2B). The water features, shaded gray in color near-infrared photography (Figure 10) occur in deflation hollows, ramp toe-slope seeps, and deflation plain wetlands. The landward retreat of the large dune ramp yields low-relief ridge-and-swale lineation's in the deflation plain. The deflation plain surface rises with proximity to the retreating dune ramp toe. Seasonal ponds and seeps occur in transverse and parabolic dune deflation troughs (lines) and along the lowermost slopes of the retreating dune ramp. Isolated tree islands (red) in the active dune field, deflect strong winds, thereby producing arcuate deflation hollows, which also host seasonal ponds. The seasonal standing water levels in the deflation hollow ponds represent proxies for the elevation and relative subsurface depth of the local GWS in the permeable late-Holocene dune deposits.

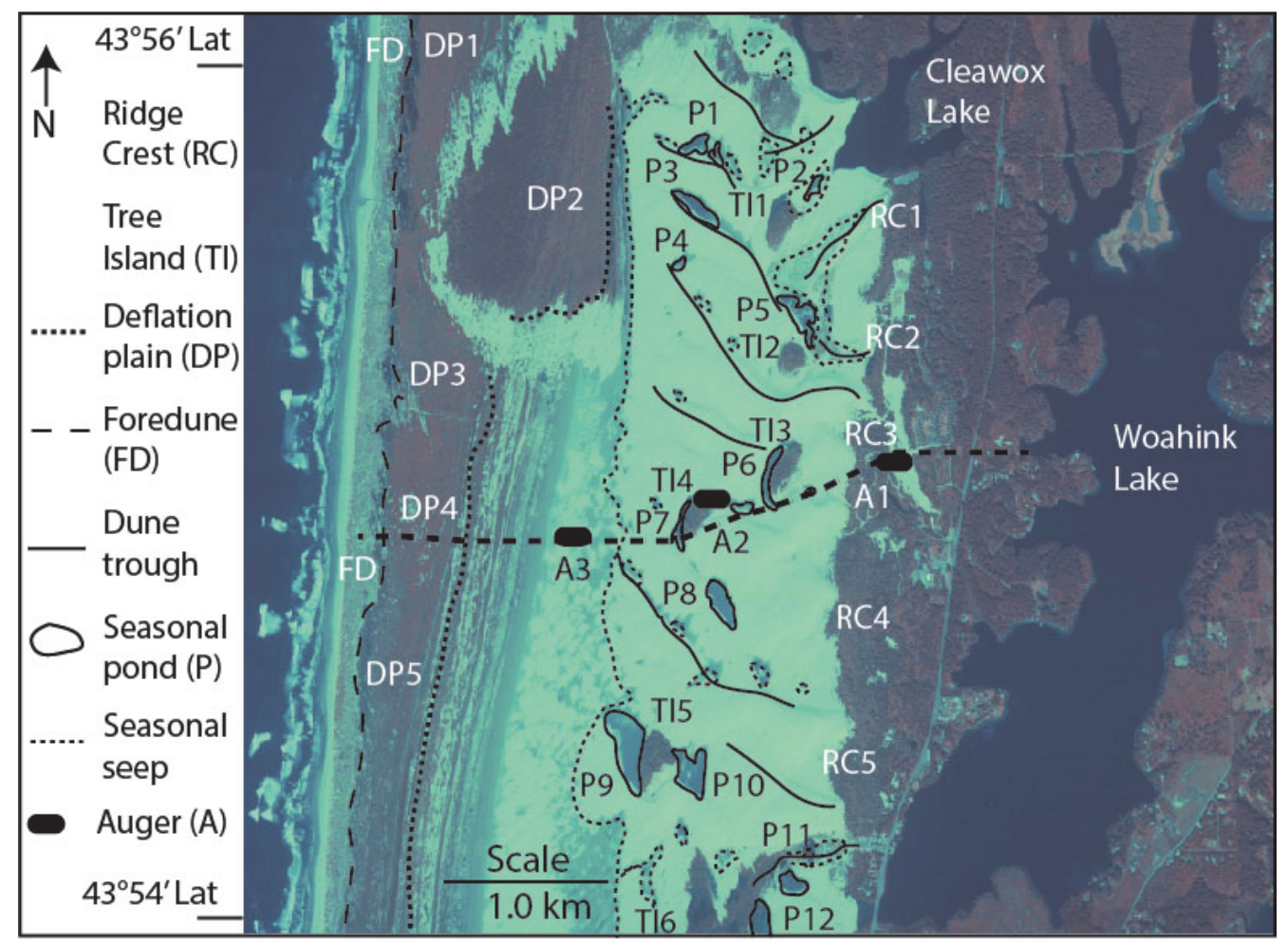

Figure 10. Aerial color near-infrared photograph (spring 2001) of 1) the Tree

Island traverse (bold dashed line) in the ATV riding area of the central FLOR dune sheet (Figure 2B) from the dune barraged Woahink Lake to the modern foredune and 2) surrounding dune and surface water features. In color near-infrared photos the lakes are black, seasonal ponds are dark gray, seasonal seeps (saturated sand) are light gray, forest vegetation is dark red, and wetland marsh is light red. Numbered dune and surface water feature elevations are shown in Table 2. Near-infrared photograph is from Chuck Rosenfeld (unpublished data, 2001) as reported in Peterson et al. (2002b).

Tabulated seasonal (spring) pond elevations in the Tree Island traverse study area (Figure 10, Table 2) yielded a mean and standard deviation of $20 \pm 4 \mathrm{~m} 1 \sigma(\mathrm{n}=12)$. The mean elevation of the seasonal ponds ( $20 \mathrm{~m} \mathrm{MSL})$, located $1.7-2.4 \mathrm{~km}$ landward distance from the ocean shoreline, is between those of the two barrage lakes Cleawox $=28 \mathrm{~m}$ and Woahink=17 m MSL. The intervening dune ramp/ridge crest ranges from 50 to $65 \mathrm{~m}$ MSL ( $\mathrm{n}=5)$. The similarity of the pond elevations argues against locally perched GWS 'held-up' by variable paleosols, hardpans or pond bottom mud seals, but rather an intersection between the sloping dune ramp surface and a slightly lower-gradient 
GWS along the north-south trending dune ramp/ridge western slope. The shallow GWS is apparently exposed in the mid-slope elevations where pond-filled deflation hollows exceed the GWS subsurface depths of $5 \pm 1 \mathrm{~m} 1 \sigma$ $(\mathrm{n}=12)$. In the lower slope elevations $(\leq 15 \mathrm{~m} \mathrm{MSL})$ the GWS reaches the dune ramp surface, as shown by widespread seasonal surface seeps, and near-surface seasonally-standing water in auger site A3 (Figure 10 and Table 2). That condition continues to the toe of the dune ramp where 1) eolian deflation is apparently reduced by increasing seasonal durations of sand saturation, and 2) perennial saturated sand is stabilized by wetland vegetation.

Table 2. Summary of dune topographic and surface water features

\begin{tabular}{|c|c|c|c|c|}
\hline Feature \# & $\begin{array}{l}\text { Feature } \\
\text { type }\end{array}$ & $\begin{array}{l}\text { Landward } \\
\text { Distance }(\mathrm{km})\end{array}$ & $\begin{array}{l}\text { Elevation } \\
\text { (m MSL) }\end{array}$ & $\begin{array}{l}\text { Dune GWS } \\
\text { depth }(\mathrm{m})\end{array}$ \\
\hline Cleawox Lake & Barrage lake & 2.6 & 28 & - \\
\hline Woahink Lake & Barrage lake & 3.6 & 17 & - \\
\hline $\mathrm{RC} 1$ & Ridge crest & 2.8 & 50 & $?$ \\
\hline $\mathrm{RC} 2$ & Ridge crest & 2.8 & 65 & $?$ \\
\hline $\mathrm{RC} 3$ & Ridge crest & 2.7 & 60 & $?$ \\
\hline $\mathrm{RC} 4$ & Ridge crest & 2.7 & 65 & $?$ \\
\hline $\mathrm{RC5}$ & Ridge crest & 2.6 & 55 & $?$ \\
\hline TI1 & Tree island & 2.2 & 30 & 7 \\
\hline TI2 & Tree island & 2.3 & 33 & 8 \\
\hline TI3 & Tree island & 2.4 & 36 & 10 \\
\hline TI4 & Tree island & 1.9 & 22 & 4 \\
\hline TI5 & Tree island & 1.8 & 21 & 4 \\
\hline TI6 & Tree island & 2.0 & 19 & 5 \\
\hline $\mathrm{P} 1$ & Seasonal pond & 1.9 & 22 & 5 \\
\hline $\mathrm{P} 2$ & Seasonal pond & 2.0 & 23 & 6 \\
\hline P3 & Seasonal pond & 1.8 & 20 & 5 \\
\hline P4 & Seasonal pond & 1.7 & 25 & 4 \\
\hline P5 & Seasonal pond & 2.4 & 28 & 6 \\
\hline P6* & Seasonal pond & 2.3 & 26 & 8 \\
\hline $\mathrm{P} 7 *$ & Seasonal pond & 1.8 & 18 & 4 \\
\hline P8 & Seasonal pond & 2.0 & 20 & 5 \\
\hline P9* & Seasonal pond & 1.7 & 17 & 4 \\
\hline P10 & Seasonal pond & 1.9 & 17 & 5 \\
\hline P11 & Seasonal pond & 2.4 & 15 & 4 \\
\hline P12* & Seasonal pond & 2.1 & 14 & 3 \\
\hline DP1 & Seasonal pond & 0.4 & 8 & $\leq 1$ \\
\hline DP2 & Seasonal pond & 1.1 & 15 & $?$ \\
\hline DP3 & Seasonal pond & 0.4 & 8 & $\leq 1$ \\
\hline DP4 & Seasonal pond & 0.4 & 9 & $\leq 1$ \\
\hline DP5 & Seasonal pond & 0.4 & 7 & $\leq 1$ \\
\hline A1 & Auger borehole & 2.9 & 45 & 8 \\
\hline $\mathrm{A} 2$ & Auger borehole & 2.1 & 31 & 7 \\
\hline A3 & Auger borehole & 1.5 & 14 & $\leq 1$ \\
\hline
\end{tabular}

Notes: Feature distances are taken landward from corresponding ocean shorelines (east to west distances). The Woahink Lake distance is taken at the intersection between the western lake shoreline and the Tree Island traverse (Figure 10). Elevations are relative to the MSL datum. Dune ramp elevations locally peak in tree island centers, so tree island elevations are taken at forest edges. Depths to seasonal (early spring) GWS are taken from differencing arcuate deflation hollow pond elevations from nearest forest edge elevations. Depths of GWS taken from the seasonal ponds, that are not attached to tree islands, are taken from differencing pond elevations from surrounding dune surfaces (average). Tree island deflation hollow pond surfaces at P6*, P7*, P9* and P12* are also differenced from surrounding dune surface elevations (averaged) to yield comparative estimates of GWS depths below the dune surfaces. Apparent seasonal seeps are assumed to represent seasonal GWS subsurface depths of $\leq 1 \mathrm{~m}$. Deflation plain wetlands (marsh) are also assumed to represent seasonal (spring) GWS depths $\leq$ $1 \mathrm{~m}$. Depths of seasonal GWS in auger boreholes are taken from subsurface depths to saturated sand or borehole wall cave-in. 
The apparent survival of isolated and partially buried, tree islands within the active dune fields of the Tree Island traverse test area (Figure 10) could also be tied to the approximate intersection between the dune ramp surface slope and the shallowing GWS in mid-slope elevations (Figure 11). The existing tree islands survived burial from vertical sand accretion by extending roots down towards the underlying GWS. The tree island forest edges average $27 \mathrm{~m}$ elevation MSL, at an average of $6 \mathrm{~m}$ above corresponding GWS depths (Table 2). Though compelling, the inferences made about the relations between dune ramp surface slopes, GWS trends, and habitats in the test study area could not be further resolved without a method of continuously mapping the subsurface GWS between the separated surface water bodies. Furthermore, remote sensing of the seasonal ponds and seeps by near infrared photography would be prohibited by dense vegetation cover in much of the Florence dune sheet. Finally, as shown by the Tree Island traverse cross-section in Figure 11 the deeper GWS trends, such as under the dune ramp/ridge crest areas, were unknown due to a lack of pond-filled deflation hollows along the ramp/ridge crest areas.

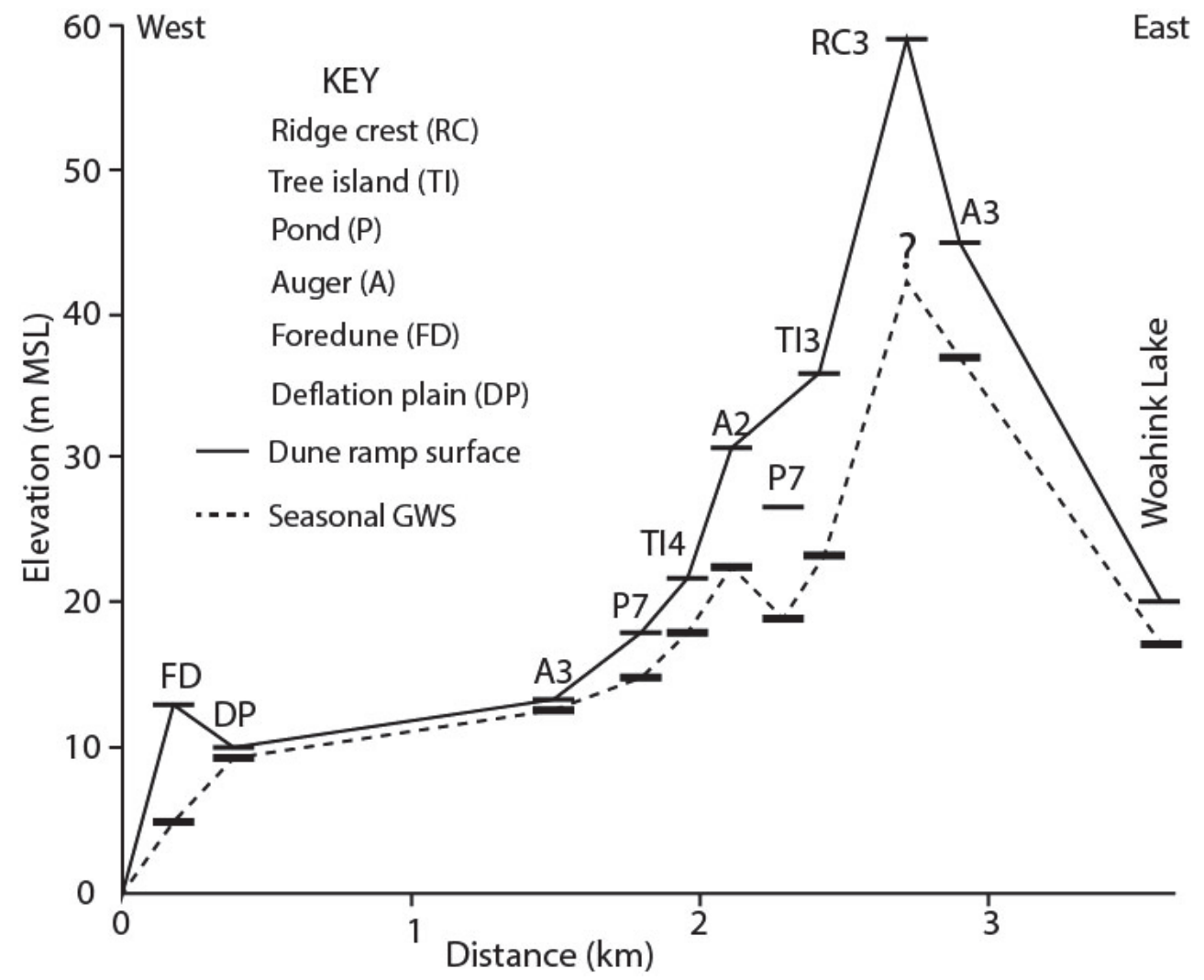

Figure 11. Cross-section of dune ramp/ridge surface and underlying seasonal

(spring) GWS, as observed in seasonal ponds, seeps, and wetlands in deflation hollows, slopes, and plains, of the Tree Island traverse in the central FLOR dune sheet (Figure 10). Distance from modern ocean shoreline $(0 \mathrm{~km}$ Distance) and elevation above modern mean sea level (0 m MSL) are taken from Table 2.

\subsection{Vehicle Towed GPR in Surveying Regional GWS Trends}

To upscale the use of GPR reflection profiling to map regional GWS trends in the FLOR dune aquifers a $1000 \mathrm{v}$ GPR system equipped with unshielded 50 or $100 \mathrm{MHz}$ antennae mounted on a carbon fiber trailer, was towed behind a continuously moving vehicle (Figure 8). Single stack pulses were taken at $1.0 \mathrm{~m}$ step spacing. An example of a test run, not corrected for topography, is shown from an east to west crossing of the South Jetty Road transect in the central FLOR dune sheet (Figure 2B) during late spring 2011. The continuous GPR profile $(3,400 \mathrm{~m}$ in length) overlaps the short hand-carried GPR profile localities, ARCH and GOOS, respectively in the dune ramp and deflation plain settings (Figures 6 and 7). The South Jetty Road transect crosses from the subaerial latePleistocene dune sheet (east), to a Holocene dune barraged Camp Lake (lake number 28 in Figure 2B and Table 1), to the Holocene dune ramp/ridge crest at $\sim 50 \mathrm{~m}$ elevation MSL (road cut grade), to the deflation plain (west) at 5-10 m elevation. In grayscale format, a strong GWS polarized reflection is traced from near surface at the barrage lake to about $12 \mathrm{~m}$ depth subsurface under the ridge crest (Figure 12A). A piezometer installed at CAMP, showed about $1.0 \mathrm{~m}$ of lake surface elevation change between winter and late summer months (John Baham, 
unpublished data, 2002). The GWS descends steeply seaward in the upper western slope of the dune ramp, at 9$10 \mathrm{~m}$ depth subsurface, but decreases in gradient to intersect the lower slope of the dune ramp below $20 \mathrm{~m}$ elevation MSL. The GWS reflection is not resolved within the $1 \mathrm{~m}$ depth subsurface resolution band across the deflation plain, which was consistent with observed standing water in a roadside drainage ditch at the time of the GPR survey. An underlying late-Pleistocene dune contact is verified at 13-14 m depth subsurface at $\sim 200 \mathrm{~m}$ distance east of the foredune (see contact in Figure 12B). The GPR signal velocity was calibrated to $0.10 \mathrm{~m} \mathrm{~ns}^{-1}$ in dry/moist sand above the GWS. As expected, the GWS deepens under the dune ramp ridge and shallows under the lowergradient valleys and plains in the relatively homogenous and permeable dune sheet deposits. Dune aquifer discharge from the ramp ridge/crest contributes to meteoric water recharge in the lower ramp slopes and deflation plain settings.

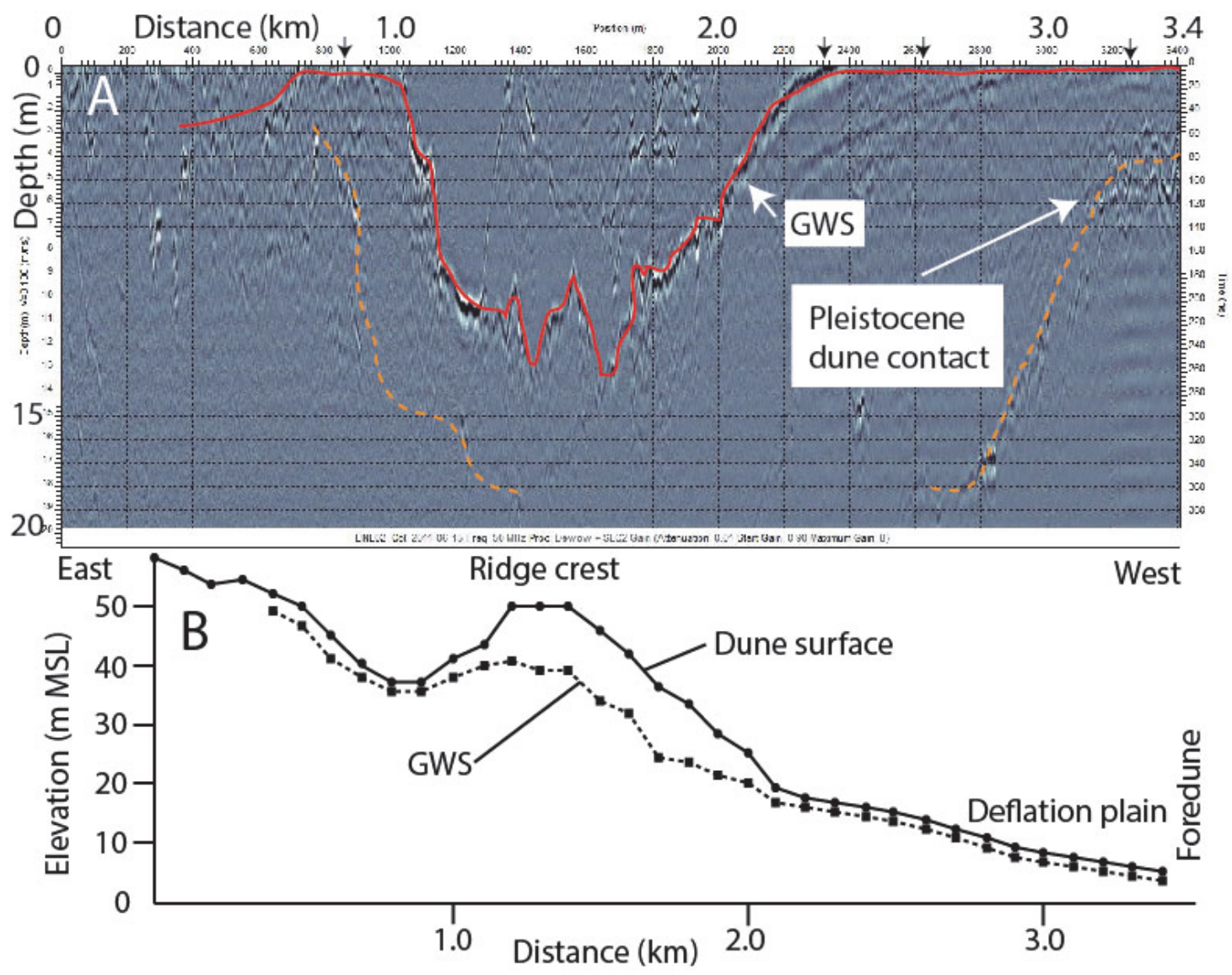

Figure 12. Part A. Minimally-processed GPR reflection profile, as seen during

GPR data collection, taken east to west across the South Jetty Road transect in the central FLOR dune sheet (Figure 2B). GWS depth ground-truthing sites were occupied (arrows) at the $860 \mathrm{~m}, 2320 \mathrm{~m}, 2620 \mathrm{~m}$, and $3250 \mathrm{~m}$ positions. The deepening GWS reflection (red) between 1.0 and $2.0 \mathrm{~km}$ track line distance, corresponds to increasing GWS depth subsurface under the elevated Holocene dune ramp/ridge surface. A weak deeper reflection (orange) is interpreted to represent the late-Pleistocene dune contact under the Holocene dune ramp. This 'inverted' preprocessed profile is what is observed during real-time GPR surveying. Part B. Depth to the GWS reflection is plotted below the transect topographic surface to show the relations between dune ramp topography and GWS trends in the South Jetty Road transect. The observed GWS trends are consistent with expected equipotential contour lines in the unconfined dune ramp/ridge aquifer.

The very shallow depths of GWS in the lower western slopes and deflation plain in the South Jetty Road transect (Figure 12B) confirm inferred relations between dune ramp topography and GWS depths in the nearby Tree Island traverse test study area (Figures 10 and 11). The continuously mapped GWS trends demonstrate that the GWS is not perched on locally developed paleosols or hardpans in late-Pleistocene dune deposits, but rather it follows near surface stream lines that are orientated orthogonal to expected equipotential contour lines in the unconfined dune 
ramp/ridge aquifer (Dingman, 1994). The GWS descends towards the ocean shoreline, intersecting the lower dune ramp slopes and deflation plain below $15 \mathrm{~m}$ elevation MSL. Due to the high permeability of the dune sand deposits the meteoric water is effectively infiltrated into the ride crest and upper slope deposits of the dune ramp during rainy winter months. The high infiltration rates greatly reduce or eliminate surface runoff in the ridge crest and upper ramp slopes during periods of precipitation. However, the relatively low-gradients of the dune ramp slopes reduce rates of lateral groundwater flow, thereby delaying aquifer discharge in the lower slopes and deflation plain into spring, summer, and early fall months. The dune ramp serves as seasonal aquifer 'sponge'. These conditions are optimal for the colonization of invasive/stabilizing non-native dune grasses, with root depths reaching at least $5 \mathrm{~m}$ subsurface depth, on the lower western dune ramp slopes ( $<20 \mathrm{~m}$ elevation MSL).

\subsection{GWS Control of Dune Barraged Lake Levels in the North FLOR Dune Sheet/Aquifer}

Following tests runs with the continuously towed GPR in the central FLOR dune sheet (Figure 12) the regional mapping of GWS in the north FLOR dune aquifer was undertaken in summer 2011 (Doliber, 2012). Initially, several GPR profiles were orientated to intersect large dune barrage lakes, such as Clear Lake and Sutton Lake (Cooper, 1958), respectively, as numbered 21 and 11 (Figure 2A) in the north FLOR dune sheet (Table 1). The lake levels were shown to coincide with the local dune aquifer GWS. Both lake and GWS elevations are estimated to be $\sim 30 \mathrm{~m}$ NAVD88 or $\sim 29 \mathrm{~m}$ MSL on the west side of the Holocene dune ramp that barrages Clear Lake (Figure 13B) and 11-12 m NAVD88 in the Sutton Creek outlet stream, located west of Sutton Lake (Figure 14B). Both lakes discharge to small outlet creeks, but both lake and outlet creek water levels are controlled by the local GWS elevation in the dune aquifer. Clear Lake is bounded to the east (landward side) by bedrock but to the west by Holocene dune sand over late-Pleistocene dune deposits (Couch et al., 1980). The Sutton Lake rim is largely bounded to the east by late-Pleistocene dune deposits and to the west (seaward side) by Holocene dune deposits. The barrage lakes are connected to the larger dune aquifer by shallow groundwater flow through both Holocene and late-Pleistocene dune deposits. However, GWS trends recorded in dune hillslopes located directly adjacent to the barrage lakes descend toward lake surfaces. The shallowest groundwater flows from dune hillslopes that surround the lakes drain directly into the lakes. Such relations in Sutton Lake indicate the potential for non-point source nitrogen and phosphorus contamination to the lake from surrounding residences. 


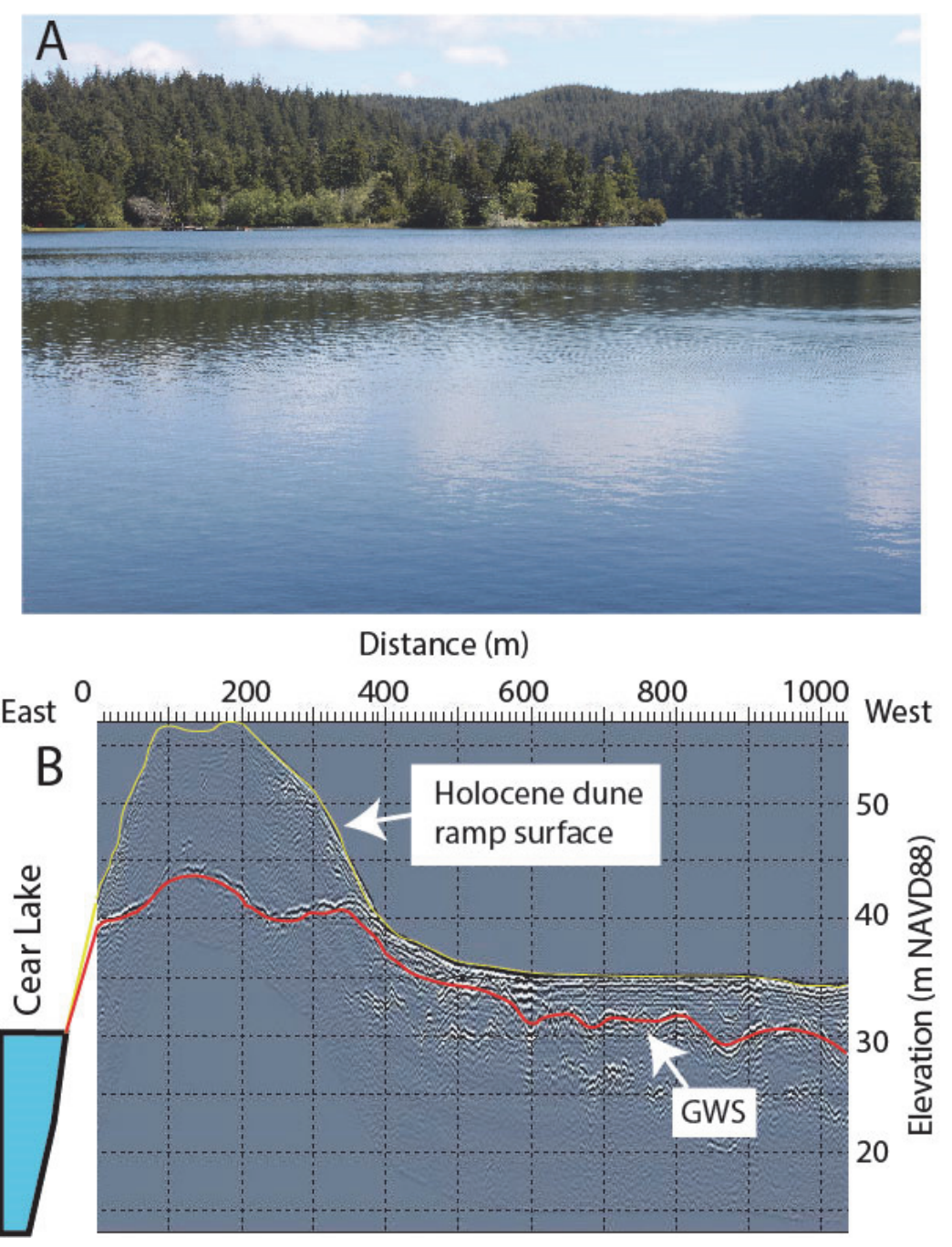

Figure 13. Part A. Photograph of Munsel Lake. Munsel Lake is the southernmost

lake in a string of elevated interconnected barrage lakes in the north FLOR dune sheet, including Collard Lake (number 18 at $37 \mathrm{~m}$ elevation), Clear Lake (number 31 at $30 \mathrm{~m}$ ), Ackereley Lake (number 23 at 30) m, and Munsel Lake (number 24 at $28 \mathrm{~m}$ ) (Figure 2A). Munsel Lake drains to Munsel Creek, which is an anadromous fish passage outlet stream (Table 1). View of Munsel Lake is to the north. Part B. Clear Lake GPR profile, located north of Munsel Lake. The profile is orientated from east to west, starting at profile position 2a in Figure 9. The GPR profile shows the Holocene dune ramp surface (yellow line) and the underlying GWS (red line). The GWS rises under the dune ridge crest and generally descends to the west in accordance with the expected dune ramp/ridge and slope equipotential contours in an unconfined aquifer. The elevations of Clear Lake, Ackereley Lake and Munsel Lake $(\sim 30 \mathrm{~m}$ NAVD88) are all controlled by the regional GWS elevation ( $30 \mathrm{~m}$ NAVD88), as surveyed over the 600 $1000 \mathrm{~m}$ track line distance in the Clear Lake GPR profile, and not by local perching from underlying impermeable bedrock, hardpans, or lake bottom mud seals. 

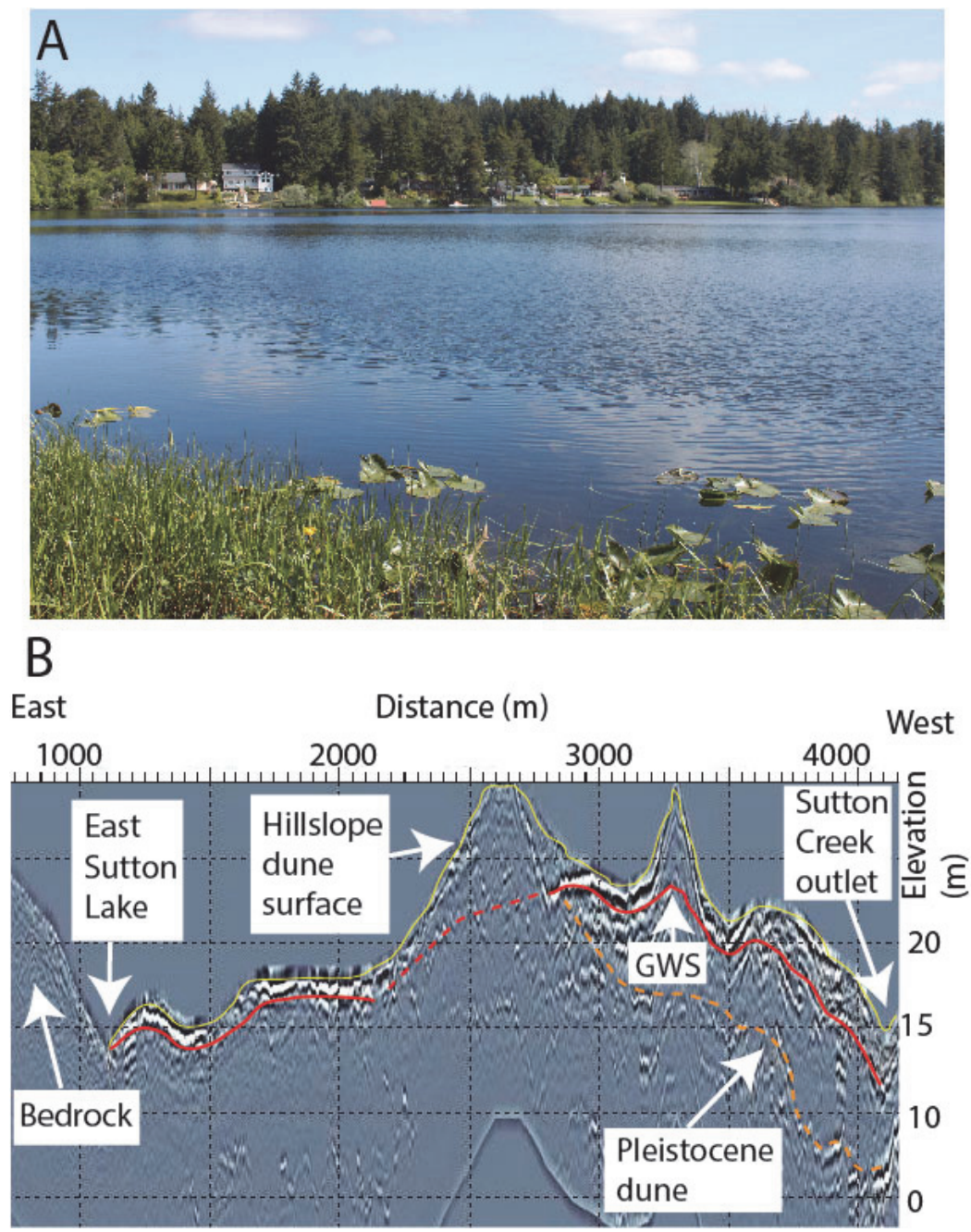

Figure 14. Part A. Photograph of Sutton Lake, the lowest barrage lake $(\sim 10 \mathrm{~m}$

NAVD88) in the north FLOR dune sheet (lake number 11 in Figure 2A). The lake is surrounded by residences on late-Pleistocene and Holocene dune hillslopes that descend towards the lake. View is to the northeast. Part B. Sutton Lake GPR profile from east to west, starting at profile position 1a in Figure 9, and continuing along the south side of Sutton Lake. The GPR profile shows the dune hillslope surface (yellow line) and the underlying GWS (red line). The lake elevation coincides with the local GWS elevation at the lake outlet (Doliber, 2012). The elevation of the outlet stream, Sutton Creek, (creek number 12 in Figure 2A) coincides with the local GWS at 1011 m NAVD88.

Selected regional-scale GRP profiles from the north FLOR dune sheet show the large-scale trends in summer GWS subsurface depths and elevations in the north FLOR dune aquifer (Figure 15). The shallow GWS generally follows the dune sheet surface topography, though GWS depths 1) increase under the larger north-south oriented dune ridges and 2) decrease with proximity to barrage lakes, outlet streams, and the deflation plain and Siuslaw Estuary. For example, the GWS elevations fall to about $5 \mathrm{~m}$ NAVD88 at 6,000 $\mathrm{m}$ track line distance in Figure 15A and to about $1 \mathrm{~m}$ NAVD88 at $0 \mathrm{~m}$ track line distance in Figure 15C. The GWS regional gradients are relatively low, ranging from $\sim 0.5$ percent in the north-south profile (Figure 15C) to $\sim 1.0$ percent in the western (seaward) side of the Sutton outlet stream profile (Figure 15B). Steeper GWS gradients ( $\sim 2.0$ percent) occur locally in some dune ridge side slopes, such as at 1000 and $2000 \mathrm{~m}$ track line distances in the Clear Lake profile (Figure 15B). The low GWS gradients account, in part, for the delayed discharge and drainage of the dune aquifer into dry summer months, which helps to maintain water levels in the dune barrage lakes, interdune ponds, and wetlands in the interior of the north FLOR dune sheet. All north FLOR dune aquifer GPR profiles, 43 in number, are provided in unmarked, topographically-corrected grayscale format in Doliber (2012). All GWS elevation sites with UTM positions, topographic surface elevations, and subsurface depth are provided in Doliber (2012). The extensive GPR and GWS 
elevation databases from Doliber (2012) can be downloaded in PDF format from https://pdxscholar.library.pdx.edu/open_access_etds/530).

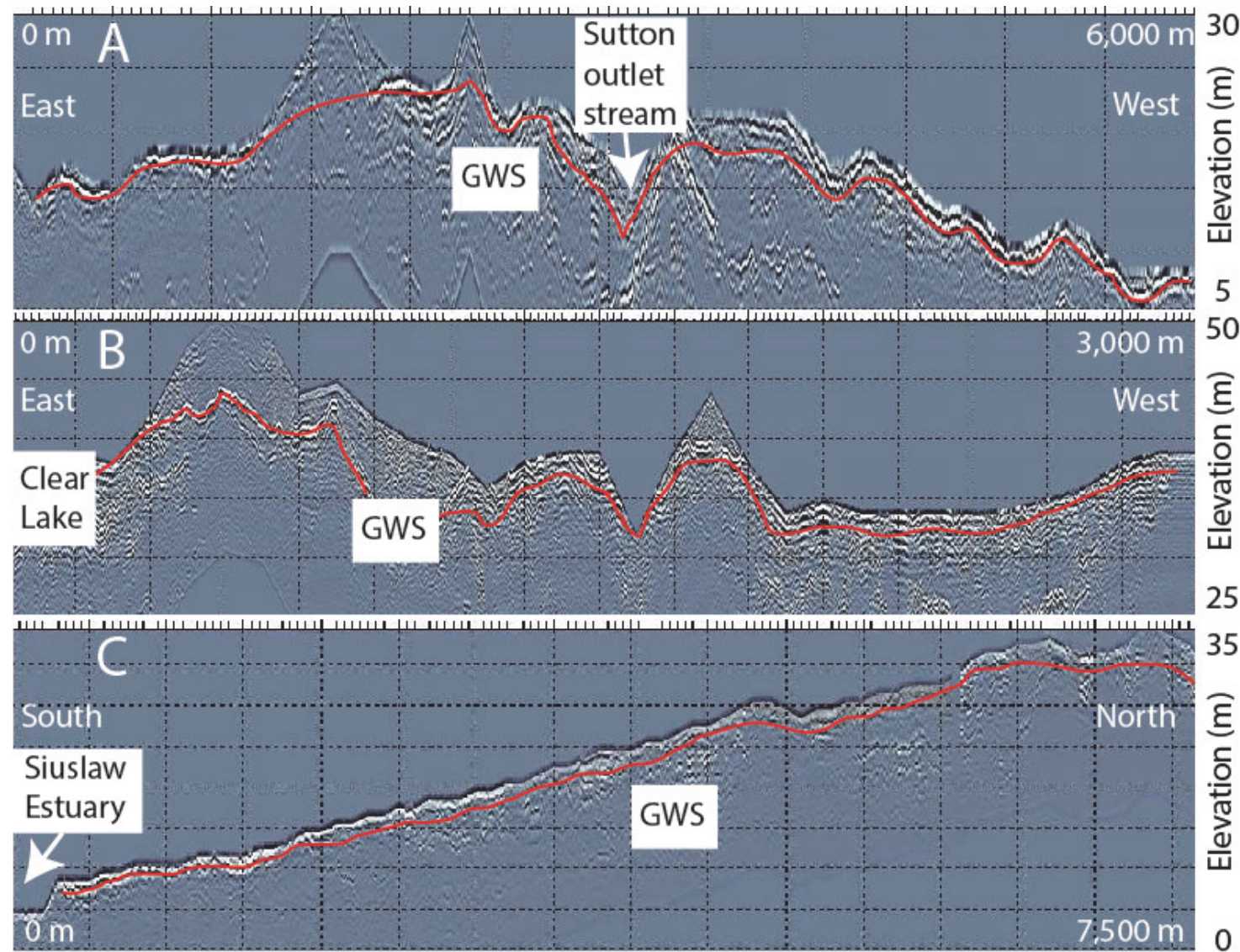

Figure 15. Part A. GPR Sutton Lake-Creek profile extending 6,000 m, generally

oriented east to west in profile 1a-1b (Figure 9). Part B. GPR Clear Lake profile extending 3,000 m east to west in profile 2a-2b. Part C. GPR HW101 profile extending 7,500 km north from the Siuslaw Estuary in profile 3a$3 b$. The shallow GWS generally follows the dune surface topography and shows no evidence of offsets or discontinuities that might be expected from perching on potential paleosol aquitards within the dune deposit aquifer.

\section{Discussion}

\subsection{Regional GWS trends and Potential Impacts from Aquifer Drawdown and Contamiant Flow}

GWS elevations from $\sim 10,000$ measured shot points were averaged over $100 \mathrm{~m}$ track line intervals to yield 943 elevation data points from 43 GPR survey profiles in the north FLOR dune sheet (Figure 9). Estimated GWS elevations ranged from 0 to $57 \mathrm{~m}$ NAVD88 in the north FLOR dune aquifer (Doliber, 2012). The normally distributed elevation data were contoured by simple kriging analysis to establish GWS elevation contours (0-55 $m$ NAVD88) and standard error (1-5 m NAVD88) in the north FLOR dune aquifer (Figure 16). Two mounds of GWS relief ( $\geq 35 \mathrm{~m}$ elevation) are shown to occur in the north and south areas of the north FLOR dune aquifer. The northern mound reaches $50 \mathrm{~m}$ elevation. The broader southern mound reaches $44 \mathrm{~m}$ elevation. The two mounds are separated by an east-west oriented trough (15-20 m elevation) which coincides with the dune barraged Sutton and Mercer Lakes and the Sutton Creek outlet stream (Figure 2A). The GWS elevations are largely controlled by dune deposit height and slope, and not by underlying bedrock or hardpan aquitards. Shallow groundwater flow is expected to flow down gradient or normal to the GWS contours (Charbeneau, 2000). In addition to the potential for local transport of shallow groundwater contaminants to lakes, pond, and outlet creeks, there is the potential for regional transport of deeper groundwater contaminants to be driven down gradient from the north and central mounds. The transport fate(s) of the potential deeper contaminants would be to the central dividing trough, at Sutton Lake and Sutton Creek, and to the Pacific Ocean shoreline and to the Siuslaw Estuary shoreline. Kriging standard error estimates are largely based on data density and distribution. Substantial GWS elevation contour errors, of up 5-6 m, are predicted for much of the northern survey area within the north FLOR dune aquifer. 
However, in the southern survey area, where most of the City development and the City's drinking water wellfields are located, the predicted standard error diminishes to 1-3 m NAVD88.

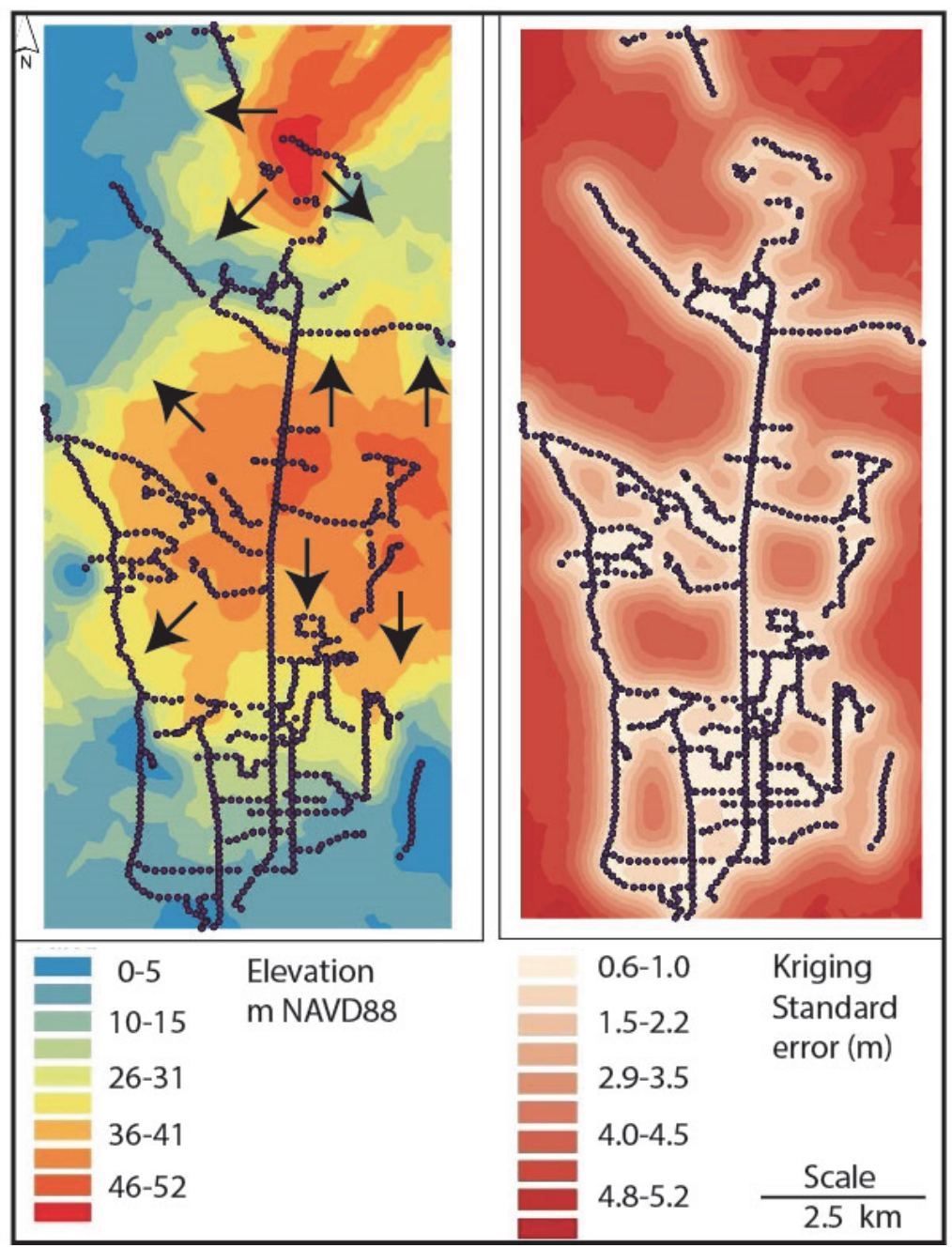

Figure 16. Plots of GWS elevation (figure left) and kriging standard error (figure

right) for the north FLOR dune aquifer from GPR surveying and window lake/pond elevations. The dune aquifer reaches maximum elevations ( $\sim 50 \mathrm{~m}$ NAVD88) in the east-central areas and generally decreases in elevation to near mean sea level with proximity to the Ocean shoreline to the west, the Siuslaw Estuary shoreline to the south, and a dividing valley near Sutton Lake to the north. Solid arrows (black) indicate potential shallow groundwater flow directions oriented perpendicular to GWS elevation contours. See Figure 9 for a corresponding Lidar hillshaded topographic map with plotted GPR track lines.

The regional distributions of GWS depths from the 943 GWS data points compiled for the north FLOR dune aquifer ranged from 1-14 m depth subsurface (Doliber, 2012). The shallow GWS depths and relatively highpermeability of the dune deposits provides good drainage but limited time for oxidative biodegradation of potential non-point source contaminants from residences, septic systems, and/or leaking sewers. Another environmental concern is the localized susceptibility of surface water bodies to GWS drawdowns from groundwater withdrawal. The connectivity of surface water features to the GWS, as mapped by GPR in the north FLOR dune aquifer, was tested at ten localities (Table 3). The ten localities were selected to include environmentally important barrage lakes, outlet streams, ponds, and wetlands. A plot of surface water feature elevation versus adjacent subsurface GWS elevation (m NAVD88) is shown in Figure 17, along with the results from a linear regression analysis for the two variables. The very-high correlation coefficient $\left(\mathrm{R}^{2}=0.98\right)$ between surface water feature elevations and corresponding GWS elevations demonstrates the susceptibility of those features to potential GWS drawdowns. Though of lesser visual attraction than the dune barrage lakes, the interdune pond and wetland habitats associated 
with elevated GWS in the north FLOR dune sheet (Figure 18) are particularly susceptible to modest GWS drawdowns, either by direct groundwater withdrawal or by potential future climate-change related droughts and decreased dune aquifer recharge.

Table 3. Elevations of surface water features and corresponding GWS elevations taken from GPR

\begin{tabular}{lllllll}
\hline $\begin{array}{l}\text { Surface } \\
\text { water }\end{array}$ & Lat & Long & $\begin{array}{l}\text { Elev. } \\
(\mathrm{m})\end{array}$ & GPR Lat & GPR Long & $\begin{array}{l}\text { GPR GWS } \\
\text { Elev. }(\mathrm{m})\end{array}$ \\
\hline Mussel Lk & 44.07305 & -124.10245 & 49 & 44.07388 & -124.09996 & 55 \\
Collard Lk & 44.03077 & -124.07964 & 37 & 44.02218 & -124.08544 & 36 \\
Wetland & 44.02839 & -124.09086 & 37 & 44.03062 & -124.08897 & 35 \\
Pond & 44.02566 & -124.11006 & 31 & 44.02810 & -124.10981 & 34 \\
Wetland & 44.02124 & -124.09670 & 33 & 44.02279 & -124.09644 & 32 \\
Wetland & 44.01819 & -124.10936 & 34 & 44.01670 & -124.11215 & 35 \\
Wetland & 43.99647 & -124.09440 & 19 & 43.99748 & -124.09644 & 20 \\
Lk Marr & 43.99071 & -124.10551 & 19 & 44.08051 & -124.10584 & 18 \\
Siuslaw R & 43.98377 & -124.08036 & 0 & 43.98732 & -124.08192 & 0 \\
Munsel Ck & 43.98231 & -124.09199 & 10 & 43.98256 & -124.09169 & 8 \\
\hline
\end{tabular}

Notes: Surface water feature elevations (m) are taken from Lidar (USGS, 2011) and are relative to the NAVD88 datum, about $1 \mathrm{~m}$ below MSL in the study area. Mapped lake, pond/wetland sites are shown in Figure 2A and Table 1.

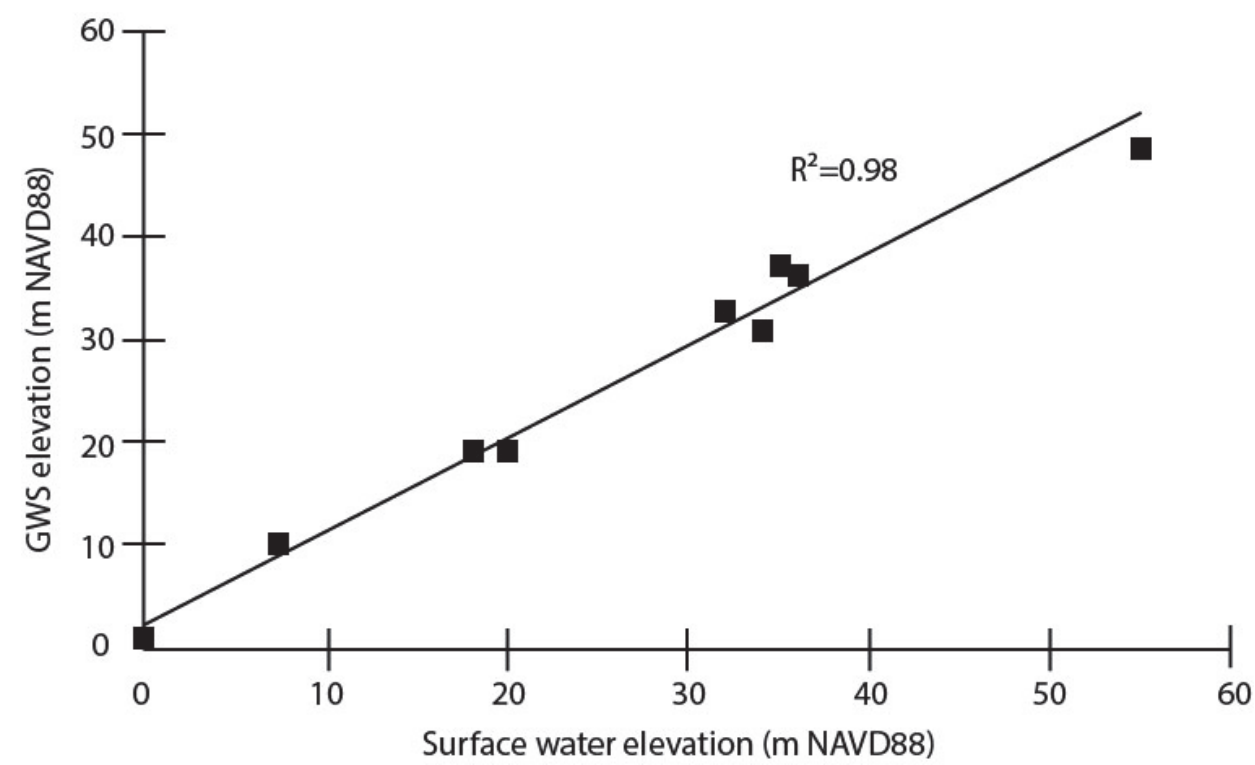

Figure 17. Plot of surface water feature elevation versus GWS elevation (m

NAVD88) for surface water bodies that were surveyed for adjacent subsurface GWS depth by GPR reflection profiling in the north FLOR dune sheet. Data are from Table 3. Surface water feature names, corresponding numbers, and mapped positions are shown in Figure 2A and Table 1. 


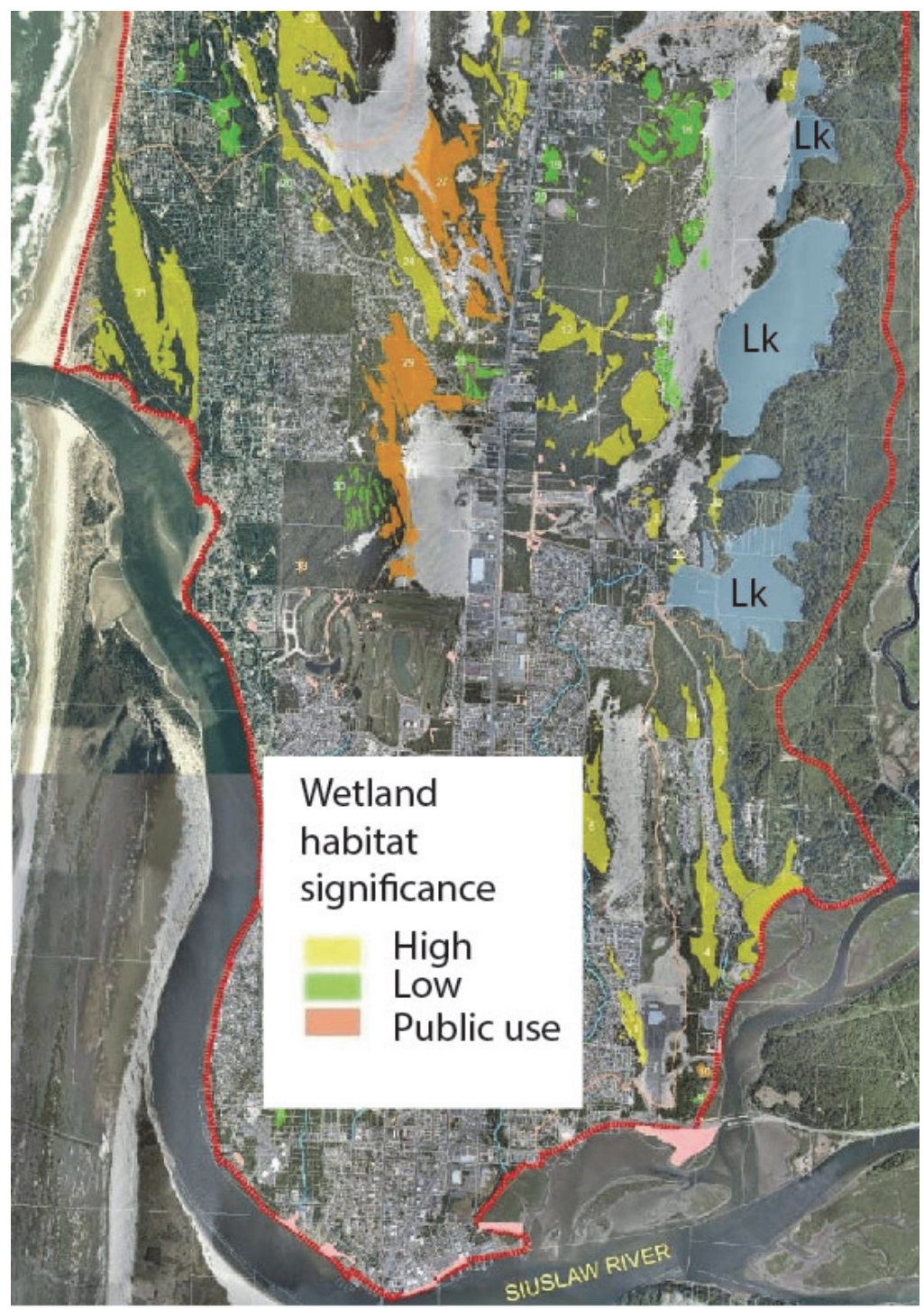

Figure 18. All the wetland habitats mapped in the north FLOR dune sheet

are directly supported by intersections between the dune topographic surface and the dune aquifer GWS, which is to say seasonal GWS of $\leq 2.0 \mathrm{~m}$ depth subsurface. A modest lowering of the dune aquifer GWS ( $\geq 2.0 \mathrm{~m}$ depth) in the mapped wetland areas would reduce or eliminate the corresponding wetland habitats. The deeper dune barrage lakes, including Collard, Clear and Munsel Lakes (blue), are less vulnerable to GWS drawdown, but their outlet streams, Sutton and Munsel Creeks (Figure 2A), could fail to reach the ocean/estuary shorelines as subaerial fish passage streams if the GWS were to be lowered by $\sim 2 \mathrm{~m}$. All georeferenced GWS depths (total of 943 points) in the north FLOR dune aquifer are provided in Doliber (2012). Map is from City of Florence (unpublished data, 2011)

In response to the dune aquifer modeling (GSI Water Solutions, 2012) and the GWS mapping by continuous GPR profiling (Doliber, 2012), along with other studies conducted for the Aquifer Protection and Wetland/Riparian Corridors program, a variety of planning documents, guidelines, and strategies have been developed by the City of Florence for the protection of the dune aquifer surface water bodies, and drinking water quality (COFPD, 2018). These include a resolution by the Florence Planning Commission (Florence Planning Commission, 2013), City planning code amendments (Florence City Code, 2013), and City and County Ordinances (Siuslaw Estuary Partnership, 2013).

\subsection{Comparative GPR-GWS Trend Study, McKenzie Lake, Fraser Island, Queensland, Australia}


In 2003-2004 a preliminary investigation of the origins of McKenzie Lake in Fraser Island, Queensland, Australia (Jol et al., 2004), was conducted by GPR profiling (Figure 19). The study was initiated, by resort and aboriginal steward interests, to establish whether the destination tourism lake was 1) connected to Fraser Island's dune aquifer as a window lake or 2) was a perched lake, presumably isolated from the larger 'regional' island dune aquifer. If McKenzie Lake is 'perched' then it could have little or no connection to potential future groundwater withdrawals by off-island municipal interests. If McKenzie Lake is 'perched' then a very-restricted area of meteoric recharge could leave the pristine lake susceptible to pollution and potential eutrophication from in-lake tourism swimming activities (Arthington and Hadwen, 2003; Harden and Bunn, 2005). By comparison to Collard Lake, the highest lake in the north FLOR due aquifer at $37 \mathrm{~m}$ elevation (Table 1), McKenzie Lake sits at $75 \mathrm{~m}$ elevation, leading to its moniker as a 'perched' lake in the very-large coastal dune complex of Fraser Island.
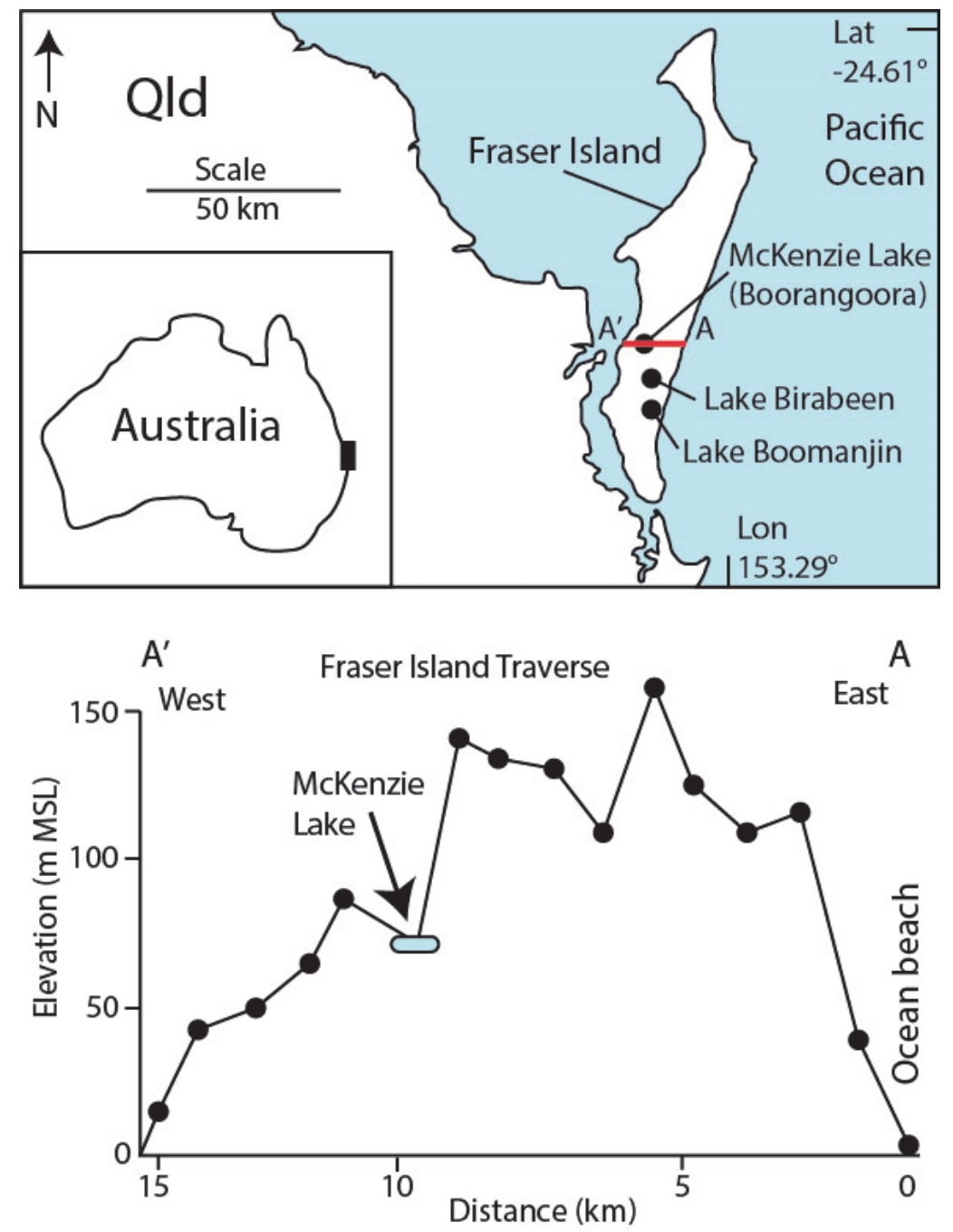

Figure 19. McKenzie Lake (Boorangoora) and a topographic profile across an

east to west traverse of Fraser Island, are shown for the very-large sand dune island on the northeast coast of Queensland (Qld), Australia. McKenzie Lake at $\sim 75 \mathrm{~m}$ elevation, together with two other interdune lakes, Birabeen and Boomanjin, are referred to as 'perched' lakes ((Arthington and Hadwen, 2003; Hadwen and Bunn, 2004), though preliminary GPR profiles around McKenzie Lake, suggest an alternative origin for the destination tourism lake, such as a lake bottom window into an elevated GWS of a mounded regional aquifer in the dune dune ramp/ridge island.

GPR surveys were conducted along the northwest and northeast shorelines of McKenzie Lake, extending 100s of meters beyond the present lake shorelines (Jol et al., 2004). The lake level coincided with the local GWS (Figure 20), which extended well beyond the present McKenzie Lake shorelines. The tentative findings of the GPR profiling study concluded that McKenzie Lake could not be confirmed to be 'perched' on a locally restricted 
aquitard such as impermeable bedrock, a paleosol or lake bottom mud seal, within $15 \mathrm{~m}$ below the lake level and mapped GWS. A plot of lake and dune ramp surface elevations on Fraser Island, like those done for the Tree Island traverse (Figure 11) and a cross-island GPR survey with a vehicle-towed GPR system, as was conducted in the South Jetty Road transect (Figure 12), are needed to formally resolve the origin and dune aquifer connections of McKenzie Lake and the other 'perched' lakes in Fraser Island.
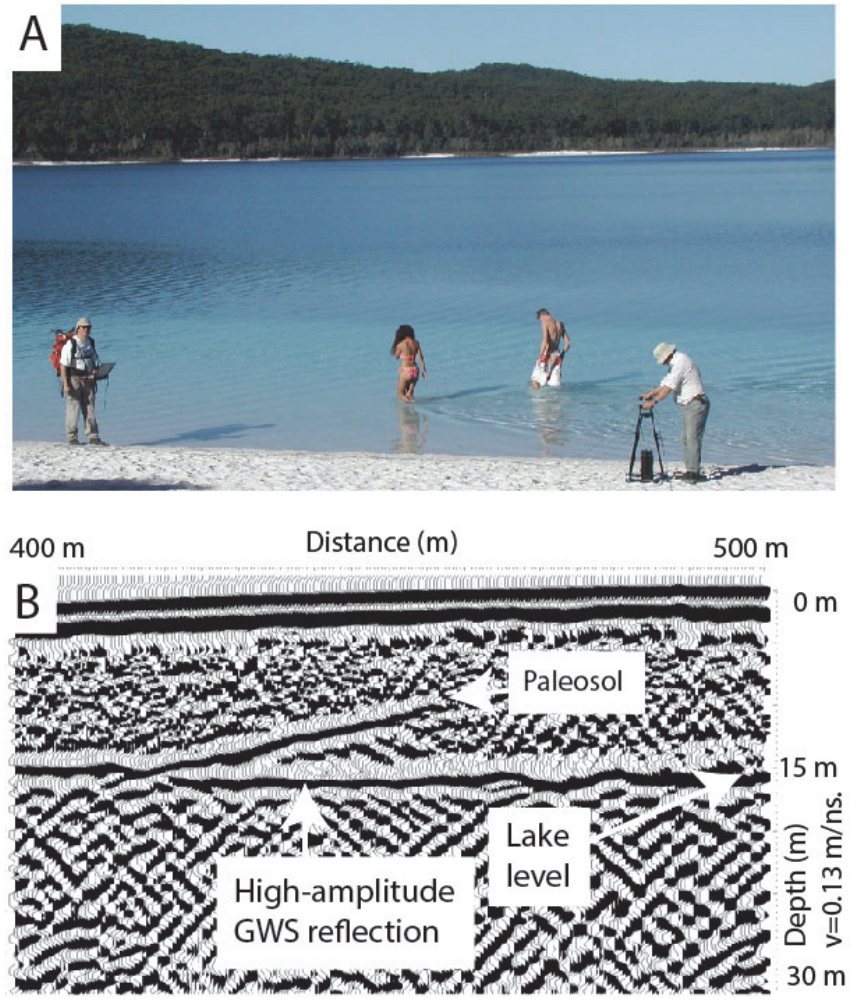

Figure 20. Part A. GPR reflection profile data collection, with $200 \mathrm{MHz}$

antennae, at McKenzie Lake or Boorangoora ( 150 ha in surface area and $\sim 5 \mathrm{~m}$ depth), located at $75 \mathrm{~m}$ MSL in the dune sand deposits of Fraser Island, Queensland, Australia. Part B. GPR profile segment (100 m in track line distance) as recorded along a sand road on the north side of McKenzie Lake, using a hand carried GPR system with $50 \mathrm{MHz}$ antennae. The subsurface GWS and the adjacent lake surface were both measured at $15 \mathrm{~m}$ depth/distance below the road surface (Jol et al., 2004). The GWS reflection extended several hundred meters beyond the present extent of the lake shorelines. Neither the lake or mapped GWS were found to be supported by shallow ( $<30 \mathrm{~m}$ depth subsurface) underlying bedrock, extensive lake bottom seals, or broad horizontal paleosols, though locally-developed inclined paleosols (Paleosol reflection) were observed in road cuts and GPR profiles around the lake shorelines. The GPR profile shown in Part B is modified from Jol et al. (2004).

\section{Conclusions}

In this article, a subsurface remote sensing instrument, ground penetrating radar (GPR), is shown to be useful in imaging the groundwater surface (GWS) of shallow aquifers in large coastal dune sheets. Such imaging and associated ground-truthing established that contamination of Cleawox Lake, and other barrage lakes, in the large FLOR dune sheet is not primarily from in-lake recreation users but rather from non-point sources of nitrogen and phosphorus contamination to the surrounding dune aquifer, which connects to the dune barrage lakes through shallow groundwater flows. Not only does shallow groundwater on the western slopes of the large FLOR dune ramp support interdune ponds and wetlands, but it also promotes the aggressive colonization of active dune surfaces by non-native invasive dune grasses. Preservation of open dune landscapes in the FLOR dune sheet will require immediate and extraordinary mitigation approaches, such as the widely expanded use of controlled recreational ATV riding. In the most densely surveyed part of the FLOR dune aquifer, the north FLOR dune aquifer, the 'water table' or groundwater surface (GWS) in the topographically complex north FLOR dune sheet is not flat. Instead, it shows substantial vertical relief or mounding, with multi-directional sloping towards the ocean and river/creek valley shorelines. The GWS elevations are controlled by high recharge rates, variable dune deposit 
heights and slopes, but not by underlying bedrock or hard pan aquitards. The shallow GWS in the north FLOR dune aquifer supports a wide variety of upland dune freshwater habitats where the dune surface topography intersects or closely approaches the dune aquifer GWS elevation. The north FLOR dune aquifer is susceptible to surface contamination and contaminant transport, generally in the down-slope directions of mapped GWS gradients. Shallow interdune ponds and wetlands are susceptible to local groundwater withdrawal and to potential lowering of the regional GWS elevations, which could result from future climate change. The direct and continuous GPR imaging of the interconnections between dune aquifer GWS trends and dune surface water bodies in the north FLOR dune aquifer helped to motivate long-term planning efforts to protect the aquifer freshwater resources.

\section{Acknowledgements}

Errol Stock directed dune deposit morphological analysis in the Florence (FLOR) dune sheet. Charles Rosenfeld performed the near infrared aerial photography in the FLOR dune sheet. Harry Jol conducted the testing of GPR profiling for GWS analysis in the central FLOR dune sheet. Courtney Cloyd, Siuslaw National Forest, arranged and supervised GPR profiling, and groundwater surface groundtruthing (drilling and coring), and elevation surveying in the Oregon Dunes National Recreation Area (ODNRA) of the FLOR dune sheet. George Grathoff and John Baham performed installations and monitoring of piezometer wells in the Goose Pasture deflation plain in the central FLOR dune sheet. Darren Beckstrand assisted with dune aquifer vibracoring and dating of Holocene and late-Pleistocene dune deposits in the FLOR dune sheet. Dennis Nelson, GSI Water Solutions Inc., performed the groundwater modeling that incorporated the GPR mapping of the GWS data in the north FLOR dune sheet. Holly Heesacker assisted with GPR equipment maintenance and field logistics for the GPR mapping of depth to GWS in the north FLOR dune sheet. Dan Graber and Frank Dietz, City of Florence Public Works Department, assisted with GPR-towing by ATV and traffic safety in the north FLOR dune aquifer. Glen Southerland, City of Florence Planning Department, provided information about the use of the Siuslaw Estuary Partnership-Aquifer Protection and Wetlands/Riparian Corridor study results (2011-2012) for the City's Planning and Regulatory efforts during the following 5-year period (2013-2018). The GPR profiling in the central FLOR dune sheet was funded by the NOAA Office of Sea Grant and Extramural Programs, U.S. Department of Commerce, under grant number NA76RG0476, project number R/SD-04, and by appropriations made by the Oregon State legislature. The drilling and dating of dune deposits from the Oregon Dunes National Recreation Area (ODNRA) was supported by the Siuslaw National Forest. The GPR mapping of the groundwater surface in the north FLOR dune aquifer was supported by the City of Florence through a grant to the City from the U.S. Environmental Protection Agency (EPA Cooperative Agreement \#WC-00J04801-0).

\section{References}

AOOL. (2018). Atlas of Oregon Lakes. Munsel Lake, Lane County, Oregon. Retrieved from https://aol.research.pdx.edu/lakes/17100206000581. Accessed April 4, 2018.

Arthington, A. H., \& Hadwen, W. L. (2003). The significance and management implications of perched dune lakes as swimming and recreation sites on Fraser Island, Australia. Journal of Tourism Studies, 14(35).

Birkeland, P. W. (1999). Soils and Geomorphology. Oxford University Press, New York. NY.

Carlson, J., Reckendorf, F., \& Ternyik, W. (1991). Stabilizing coastal sand dunes in the Pacific Northwest. United States Department of Agriculture, Soil Conservation Service, Agriculture Handbook 687. 53 p.

Charbeneau, R. J. (2000). Groundwater Hydraulics and Pollutant Transport. Prentice Hall. Upper Saddle River, NJ. $591 \mathrm{p}$.

Christy, J. A., Kagan, J. S., \& Wiedemann, A. M. (1998). Plant associations of the Oregon Dunes National Recreation Area: Siuslaw National Forest, Oregon. United States Department of Agriculture, Forest Service, Pacific Northwest Region.

City of Florence. (2013). Siuslaw Estuary Partnership - Aquifer Protection and Wetland/Riparian Corridors. City of Florence, Florence, Oregon. Retrieved April 1, 2018, from http://www.ci.florence.or.us/planning/siuslawestuary-partnership-aquifer-protection-and-wetlandriparian-corridors

COFPD. (2013). Florence Realization 2020 Comprehensive Plan. City of Florence Planning Department. Florence, Oregon. Available on-line. Retrieved April 18, 2018, from http://www.oregon.gov/LCD/OCMP/docs/Public_Notice/florencecomp_plan_marked2.pdf

Cooper, W. S. (1958). Coastal sand dunes of Oregon and Washington. Geological Society of America. Memoirs. 72, 169. https://doi.org/10.1130/MEM72-p1

Couch, R., Cook, J., Connard, G., Troseth, S., \& Standing, W. (1980). North Florence Dunal Aquifer Study, Seismic 
Survey Subreport. Lane County Services Bureau, Eugene, Oregon, 41 p. and maps.

Daggett, S. G., Vogel, A. H., \& Petersen, R. R. (1996). Eutrophication of Mercer, Munsel, and Woahink Lakes, Oregon. Northwest Science, 70, 28-38.

Daniels, D. J. (1996). Surface-Penetrating Radar. Institute of Electrical Engineers, London, UK. https://doi.org/10.1049/ecej:19960402

Dingman, S. L. (1994). Physical Hydrology, Macmilian Publishing Company, New York, NY, pp. 312-316.

Doliber, S. R. (2012). Groundwater surface trends in the North Florence Dunal Aquifer, Oregon Coast, USA. (M.S. Thesis), Portland State University, 104 p. Dissertations and Theses. Paper 530. Retrieved from https://pdxscholar.library.pdx.edu/open_access_etds/530 10.15760/etd.530

Doolittle, J. A., Jenkinson, B., Hopkins, D., Ulmer, M., \& Tuttle, W. (2006). Hydropedological investigations with ground-penetrating radar (GPR): Estimating water-table depths and local ground-water flow pattern in areas of coarse-textured soils. Geoderma, 131,317-329. https://doi.org/10.1016/j.geoderma.2005.03.027

Florence City Code. (2013). Drinking Water Protection Overlay District. Title 10, Chapter 32. DRINK. WATER PROT. OV. ZONE. 10-32, City of Florence, Oregon. $7 \mathrm{p}$.

Florence Planning Commission. (2013). Siuslaw Estuary Partnership - Aquifer Protection and Wetland/Riparian Corridors. Resolution PC 1303 CPA 01 \& PC 1304 TA 01 \& PC 1305 ZC 01, Florence Planning Commission. $\quad$ Retrieved April 10, 2018, from http://www.ci.florence.or.us/sites/default/files/fileattachments/planning/page/637/pc_resolution_sep_5-713_final.pdf

Google Earth. (2018). Google Earth Imagery 2016. https://www.google.com/earth/.Accessed April 27, 2018.

GSI Water Solutions. (2012). Delineation of Drinking Water Protection Areas, City of Florence, Oregon. GSI Ground Water Solutions Inc., Eugene, Oregon. Final Report submitted to Oregon Health Authority's Drinking Water Program, Salem, Oregon. 27 p.

Hacker, S. D., Zarnetske, P., Seabloom, E., Ruggiero, P., Mull, J., Gerrity, S., \& Jones, C. (2012). Subtle differences in two non-native congeneric beach grasses significantly affect their colonization, spread, and impact. Oikos, 121, 138-148. https://doi.org/10.1111/j.1600-0706.2011.18887.x

Hadwen, W. L., \& Bunn, S. E. (2004). Tourists increase the contribution of autochthonous carbon to littoral zone food webs in oligotrophic dune lakes. Marine and Freshwater Research, 55, 701-708. https://doi.org/10.1071/MF04068

Hadwen, W. L., \& Bunn, S. E. (2005). Food web responses to low-level nutrient and $15 \mathrm{~N}$-tracer additions in the littoral zone of an oligotrophic dune lake. Limnology and Oceanography, 50, 1096-1105. https://doi.org/10.4319/lo.2005.50.4.1096

Hafenrichter, A. L. (1967). Lassoing the West's rampaging sand dunes. 1967 Yearbook of Agriculture, pp. 317321.

Hampton, E. R. (1963). Ground Water in the Coastal Dune Area Near Florence, Oregon. Geological Survey WaterSupply Paper 1539-Km, 36p.

Harari, Z. (1996). Ground-penetrating radar (GPR) for imaging stratigraphic features and groundwater in sand dunes. Journal of Applied Geophysics, 36, 43-52. https://doi.org/10.1016/S0926-9851(96)00031-6

Heikkinen, O. (1994). The Pacific Northwest coastal dunes-human influence and natural changes. Terra. 106, 267-276.

Hunter, R. E., Richmond, B. M., \& Rho Alpha, T. A. U. (1983). Storm-controlled oblique dunes of the Oregon coast. Geological Society of America Bulletin, 94, 1450-1465. https://doi.org/10.1130/00167606(1983) $94<1450:$ SODOTO $>2.0 . C O ; 2$

Jol, H. M., \& Bristow, C. S. (2003). GPR in sediments: Advice on data collection, basic processing, and interpretation, a good practice guide, In C.S. Bristow \& H.M Jol, (Eds)., GPR in Sediments. Geological Society [London] Special Publication, 211, 9-27. https://doi.org/10.1144/GSL.SP.2001.211.01.02

Jol, H. M., Peterson, C., Stock, E., \& Greenway, C. (2004). Preliminary results from GPR stratigraphic studies on Fraser Island, Austalia. Tenth International Conference on Ground Penetrating Radar, Delft, The Netherlands, $5 \mathrm{p}$.

Kavanagh, R. C. (1973). A comparative analysis of four Oregon coastal lakes on the basis of description, trophy, 
and density-dependent functions. (M.S Thesis) Oregon State University, Corvallis, Oregon. 117 p.

Minor, R., Greenspan, R. L., Hughes, R. E., \& Tasa, G. L. (1999). Siuslaw dune site: archaeology and environmental change in the Oregon Dunes. In R.J., Losey, (Ed)., Changing Landscapes: Proceedings of the Third Annual Coquille Cultural Preservation Conference, 2000. Coquille Indian Tribe, North Bend, Oregon, pp. 82-102.

ODFW. (2018). Coastal Multi-Species Conservation and Management Plan. Oregon Department Of Fish and Wildlife, Salem, Oregon.https://www.dfw.state.or.us/fish/crp/coastal_multispecies.asp. Accessed April 20, 2018.

Oregon State Parks. (2018). Darlingtonia State Natural Site. Oregon State Parks.

Peterson, C. D., Grathoff, G. H., Reckendorf, F., Percy, D. \& Price, D. M. (2014). Late Pleistocene coastal loess deposits of the central west coast of North America: Terrestrial facies indicators for marine low-stand intervals. Aeolian Research, 12, 47-64. https://doi.org/10.1016/j.aeolia.2013.11.001

Peterson, C. D., Jol, H. M. Percy, D., \& Nielsen, E. L. (2007b). Groundwater surface trends from ground penetrating radar (GPR) profiles taken across late-Holocene barriers and beach plains of the Columbia River littoral system, Pacific Northwest coast, USA. Geological Society of America, special paper 432, p. 59-76.

Peterson, C. D., Stock, E., Hart, R., Percy, D., Hostetler, S. W., \& Knott, J. R., (2009). Holocene coastal dune fields used as indicators of net littoral transport: West Coast, USA. Geomorphology, 116, 115-134. https://doi.org/10.1016/j.geomorph.2009.10.013

Peterson, C. D., Stock, E., Price, D. M., Hart R., Reckendorf, F., Erlandson, J. M., \& Hostetler, S. W. (2007a). Ages, distributions, and origins of upland coastal dune sheets in Oregon, USA, Geomorphology, 91, 81-102. https://doi.org/10.1016/j.geomorph.2007.02.005

Peterson, C., Baham, J., Beckstrand, D., Clough C., Cloyd, C., Erlandson, J., Grathoff, G., Hart, R., Jol, H., Percy, D., Reckendorf, F., Rosenfeld, C., Smith, T., Phyllis Steeves, P., \& Stock, E. (2002a). Field guide to the Pleistocene and Holocene dunal landscapes of the Central Oregon Coast: Newport to Florence, Oregon. Geological Society of America, Field Trips Guide, Cordillera Meeting, Corvallis, Oregon, 13 p.

Peterson, C., Baham, J., Beckstrand, D., Clough C., Cloyd, C., Erlandson, J., Grathoff, G., Hart, R., Jol, H., Percy, D., Reckendorf, F., Rosenfeld, C., Smith, T., Phyllis Steeves, P., \& Stock, E. (2002b). Virtual field trip to the Pleistocene and Holocene dunal landscapes of the Central Oregon Coast: Sea Grant Publications, $40 \mathrm{p}$.

Peterson, C., Stock, E., Cloyd, C., Beckstrand, D., Clough, C., Erlandson, J., Hart, R., Murillo- Jiménez, Percy, D., Price, D., Reckendorf, F. \& Vanderburgh, S. (2006). Dating and morphostratigraphy of coastal dune sheets from the central west coast of North America. Oregon Sea Grant Publications, Corvallis, Oregon, 81p.

Reckendorf, F. F. (1975). Beaches and Dunes of the Oregon Coast. U.S. Department of Agriculture, Oregon Department of Soil Conservation Service, and Oregon Coastal Conservation and Development Commission, $161 \mathrm{p}$.

Rejiba, F., Bobée, C., Maugis, P. \& Camerlynck, C. (2012). GPR imaging of a sand dune aquifer: A case study in the niayes ecoregion of Tanma, Senegal. Journal of Applied Geophysics, 81, 16-20. https://doi.org/10.1016/j.jappgeo.2011.09.015

Save Oregon's Dunes. (2016). Restoring Oregon's Dunes. Save the Oregon Dunes. Retrieved April 5, 2018, from https://www.saveoregondunes.org/wp-content/uploads/2018/02/Dunes-Restoration-Strategy.pdf

Shultz, S. T. (1998). Dunes and Freshwater Wetlands. The Northwest Coast, A Natural History. Timber Press, Portland, Oregon, pp 223-253.

Siuslaw Estuary Partnership. (2013). City of Florence Ordinance No. 2, Series 2013. Lane County Ordinance No. PA 1299. City of Florence, Oregon, 107.

USGS. (2011). USGS Ned 1/9 arc sec Topographic Data. Retrieved February 15, 2011, from http://seamless.usgs.gov

\section{Copyrights}

Copyright for this article is retained by the author(s), with first publication rights granted to the journal.

This is an open-access article distributed under the terms and conditions of the Creative Commons Attribution license (http://creativecommons.org/licenses/by/4.0/). 